\title{
A regionally resolved inventory of High Mountain Asia surge-type glaciers, derived from a multi-factor remote sensing approach
}

\author{
Gregoire Guillet ${ }^{1}$, Owen King ${ }^{1}$, Mingyang Lv ${ }^{2}$, Sajid Ghuffar ${ }^{1}$, Douglas Benn ${ }^{1}$, Duncan Quincey ${ }^{3}$, and \\ Tobias Bolch ${ }^{1}$ \\ ${ }^{1}$ School of Geography and Sustainable Development, University of St Andrews, United Kingdom of Great Britain and \\ Northern Ireland \\ ${ }^{2}$ Aerospace Information Research Institute, Chinese Academy of Sciences, Beijing, 100094, China \\ ${ }^{3}$ School of Geography, University of Leeds, United Kingdom of Great Britain and Northern Ireland
}

Correspondence: Gregoire Guillet (gg70@st-andrews.ac.uk)

\begin{abstract}
Knowledge about the occurrence and characteristics of surge-type glaciers is crucial due to the impact of surging on glacier melt and glacier related hazards. One of the "super-clusters" of surge-type glaciers is the mountains of Asia. However, no consistent region-wide inventory of surge-type glaciers in High Mountain Asia exists. We present a regionally resolved inventory of surge-type glaciers based on their behaviour across High Mountain Asia between 2000 and 2018. We identify surge-type behaviour from surface velocity, elevation and feature change patterns using a multi-factor remote sensing approach that combines yearly ITS_LIVE velocity data, DEM differences and very-high resolution imagery (Bing Maps, Google Earth). Out of the $\approx 95000$ glaciers in HMA, we identified 666 that show diagnostic surge-type glacier behaviour between 2000 and 2018, which are mainly found in the Karakoram (223) and the Pamir regions (223). The total area covered by the 666 surgetype glaciers represents $19.5 \%$ of the glacierized area in Randolph Glacier Inventory (RGI) V6.0 polygons in HMA. Across all regions of HMA, the surge-affected area within glacier complexes displays a significant power law dependency with glacier length. We validate 107 previously identified glaciers as surge-type and newly identify 491 glaciers. We finally discuss the possibility of self-organized criticality in glacier surges.
\end{abstract}

\section{Introduction}

Glacier surges are internally triggered, quasi-periodic oscillations of a glacier's dynamical behaviour, alternating between slow and fast flow (Meier and Post, 1969; Raymond, 1987; Sharp, 1988; Truffer et al., 2021). While periods of slow flow (or quiescence) usually last for tens to hundreds of years, periods of fast flow (surge) are shorter (months to 15 years), with flow velocity reaching up to 10-1000 times its standard order of magnitude (Meier and Post, 1969; Murray et al., 2003; Pritchard et al., 2005; Mansell et al., 2012). During surges, a substantial volume of ice is transferred from a reservoir zone down-glacier to a receiving zone. This mass transfer typically leads to drastic thinning in the upper reaches of the glacier and thickening at lower elevations, often causing a substantial advance of the glacier terminus (see Sund et al. (2009) for example).

Glacier surges can occur on both polythermal and temperate glaciers. In the former case, the bed can oscillate between cold and warm states over the course of a surge cycle, whereas in the latter the bed remains warm throughout. These two cases have 
https://doi.org/10.5194/tc-2021-303

Preprint. Discussion started: 6 October 2021

(C) Author(s) 2021. CC BY 4.0 License.

\section{(c) (i)}

been used as the basis for a two-fold classification of surge-type glaciers ("Svalbard-type" vs. "Alaskan-type") with distinct instability mechanisms ("thermal switch" and "hydrological switch", respectively) (Murray et al., 2003; Jiskoot et al., 2001). This binary view, however, reflects neither the wide diversity of surging behaviour (see Quincey et al. (2015) for example) nor the consistent associations between surging and climate, glacier geometry, and substrate characteristics. Benn et al. (2019) have argued that the full spectrum of glacier dynamic behaviour can be understood in terms of basal enthalpy balance. That is, stable steady states (non-surging behaviour) are only possible if enthalpy (thermal energy and water) generated at glacier beds from geothermal heat, friction and other sources can be evacuated from the system at the same rate. Imbalances between enthalpy inputs and outputs result in dynamic instabilities, including surges. Some combinations of regional (climatic) and local (topographic, geologic) factors encourage instability, consistent with observations (Sevestre and Benn, 2015). Many aspects of enthalpy balance theory need to be worked out in detail (e.g. interactions between ice motion, friction and basal drainage), and predictions of the theory need to be tested against local and regional datasets.

Surge-type behaviour has been documented for around 1\% of glaciers worldwide (Jiskoot et al., 2000; Sevestre and Benn, 2015), with two main "super-clusters" : High Mountain Asia (HMA) and the so called "Arctic Ring" (Alaska, Arctic Canada, Svalbard, and Russian High Arctic) (Sevestre and Benn, 2015). Surge-type glaciers throughout HMA have received significant attention in the past decades, with many regional inventories being generated, especially in the Karakoram (Hewitt, 1969; Kotlyakov et al., 1997; Barrand and Murray, 2006; Quincey et al., 2011; Copland et al., 2011; Bolch et al., 2017), Pamirs (Osipova et al., 1998; Kotlyakov et al., 2008; Shangguan et al., 2016; Lv et al., 2019; Goerlich et al., 2020) and Tien Shan (Osmonov et al., 2013; Häusler et al., 2016; Mukherjee et al., 2017; Zhou et al., 2021). More recently, glacier surges have been documented in understudied regions of HMA such as the Tibetan Plateau (King et al., 2021; Xu et al., 2021; Zhu et al., 2021) and Western Kunlun Shan (Yasuda and Furuya, 2013, 2015; Chudley and Willis, 2019; Muhammad and Tian, 2020). Many of these studies have focused on the modern satellite era and highlighted the non-uniform distribution surge-type glaciers in HMA, giving a more accurate representation of the prevalence of surge-type glaciers compared to ground based efforts (Kotlyakov et al., 2008; Imran and Ahmad, 2021). Yet, no HMA-wide inventory of surge-type glaciers exists.

The cyclical advance of surge-type glaciers can result in repeated and widespread glacier hazard formation (Gardner and Hewitt, 1990; Ding et al., 2018; Bhambri et al., 2019; Truffer et al., 2021). Hazards associated with surge-type glaciers impact both the local environment in the path of the advancing glacier terminus (Shangguan et al., 2016) and communities further downstream, in the path of meltwater produced by glaciers at the head of mountain catchments. The source of many large Glacial Lake Outburst Floods (GLOFs) in the Karakoram can be traced back to lakes which have formed behind the advancing terminus of a surge-type glacier (Hewitt and Liu, 2010; Bhambri et al., 2019). The timing and magnitude of the drainage of such lakes is difficult to predict because of the active nature of the lake's ice dam, but several GLOFs may occur from the same lake during the active phase of the damming glacier (Round et al., 2017; Gao et al., 2021; Bazai et al., 2021). The recent surge and associated glacial lake formation alongside Shishpare Glacier (Bhambri et al., 2020) is just one example of the threat posed by surge-related hazards to high mountain infrastructure such as the International Karakoram Highway - a route which provides a vital link to mountain communities in southwest China/Tibet and Pakistan (Ding et al., 2018). 
https://doi.org/10.5194/tc-2021-303

Preprint. Discussion started: 6 October 2021

(C) Author(s) 2021. CC BY 4.0 License.

(c) (i)

The impact of ice redistribution through a glacier surge's cycle on its overall rate of mass loss or gain (mass balance) over multi-decadal timescales is still disputed. The flux of ice from a surge-type glacier's reservoir zone to its receiving zone results in the redistribution of a large ice volume to lower altitude, where it is more prone to ablation (Sund et al., 2009; King et al., 2021). Studies documented increased melt rate in the expanded ablation zone, outpacing the rate of quiescent phase ice buildup in the years following surge cessation, and leading to markedly more negative mass balance (Aðalgeirsdóttir et al., 2005; Kochtitzky et al., 2019; King et al., 2021). Similarly, synchronous surging by a number of glaciers in the Ak-Shirak region of the Northern Tien Shan resulted in enhanced ice loss in the 1980s and 1990s when no significant change in temperature or precipitation otherwise occurred to drive enhanced ablation (Bhattacharya et al., 2021). The surge-related fluctuation of individual glacier mass balance does not appear pronounced enough to influence regional ice loss rates over shorter time scales amongst the larger surge-type glacier clusters, such as the Karakoram (Gardelle et al., 2013; Berthier and Brun, 2019). A detailed inventory of surge-type glaciers is clearly important for a region such as HMA, where glacier hazard mitigation and glacier meltwater yield will be a high priority as the temperatures of the region are projected to further rise in coming decades (Kraaijenbrink et al., 2017; Bolch et al., 2019; Lalande et al., 2021).

The objectives of this paper are twofold. First, we aim to assess the occurrence of surge-type glaciers across HMA using remotely sensed data spanning the period 2000-2018. Then, we aim to clarify what are the main controls for surging in HMA, as well as providing a clearer image of the spectrum of possible surge behavior, in light of the enthalpy balance theory (Benn et al., 2019).

\section{Data and methods for surge-type glacier identification}

75 We propose to identify surge-type glaciers from distinct widely used criteria (Dowdeswell and Williams, 1997; Copland et al., 2003; Grant et al., 2009), directly contrasting with regional trends of glacier mass loss (Brun et al., 2017; Shean et al., 2020; Bhattacharya et al., 2021), slow down (Dehecq et al., 2019) and retreat (Li et al., 2019). First, substantial and spatially concentrated surface elevation changes, either in the reservoir zone or at lower elevations (near the glacier terminus), are assumed to be typical of surge-type glacier ice mass redistribution. Then, substantial variations in a glacier's velocity field is taken as indicative of surging. Finally, we consider chaotic glacier-wide crevasse patterns mixing longitudinal and transverse crevasses at low altitudes (typically close to the front) as diagnostic of active glacier surges. While terminus advance is often a consequence of glacier surges, not all surge-type glaciers display terminal advance during the active phase and it is therefore not considered as a discriminating criterion for surge identification (Paul et al., 2017; Steiner et al., 2018).

\subsection{Glacier surface elevation changes}

85 We considered two contrasting patterns of glacier surface elevation change to be diagnostic of surge-type glaciers. We aimed to identify glaciers which exhibited substantial and widespread surface elevation gain (thickening) over their receiving zone, which is also commonly accompanied by surface elevation decrease (thinning) over a glacier's reservoir zone due to the flux of ice between the two areas (Figure 1 (A)). We consider this pattern of elevation change to be diagnostic of the active phase of a 
https://doi.org/10.5194/tc-2021-303

Preprint. Discussion started: 6 October 2021

(c) Author(s) 2021. CC BY 4.0 License.
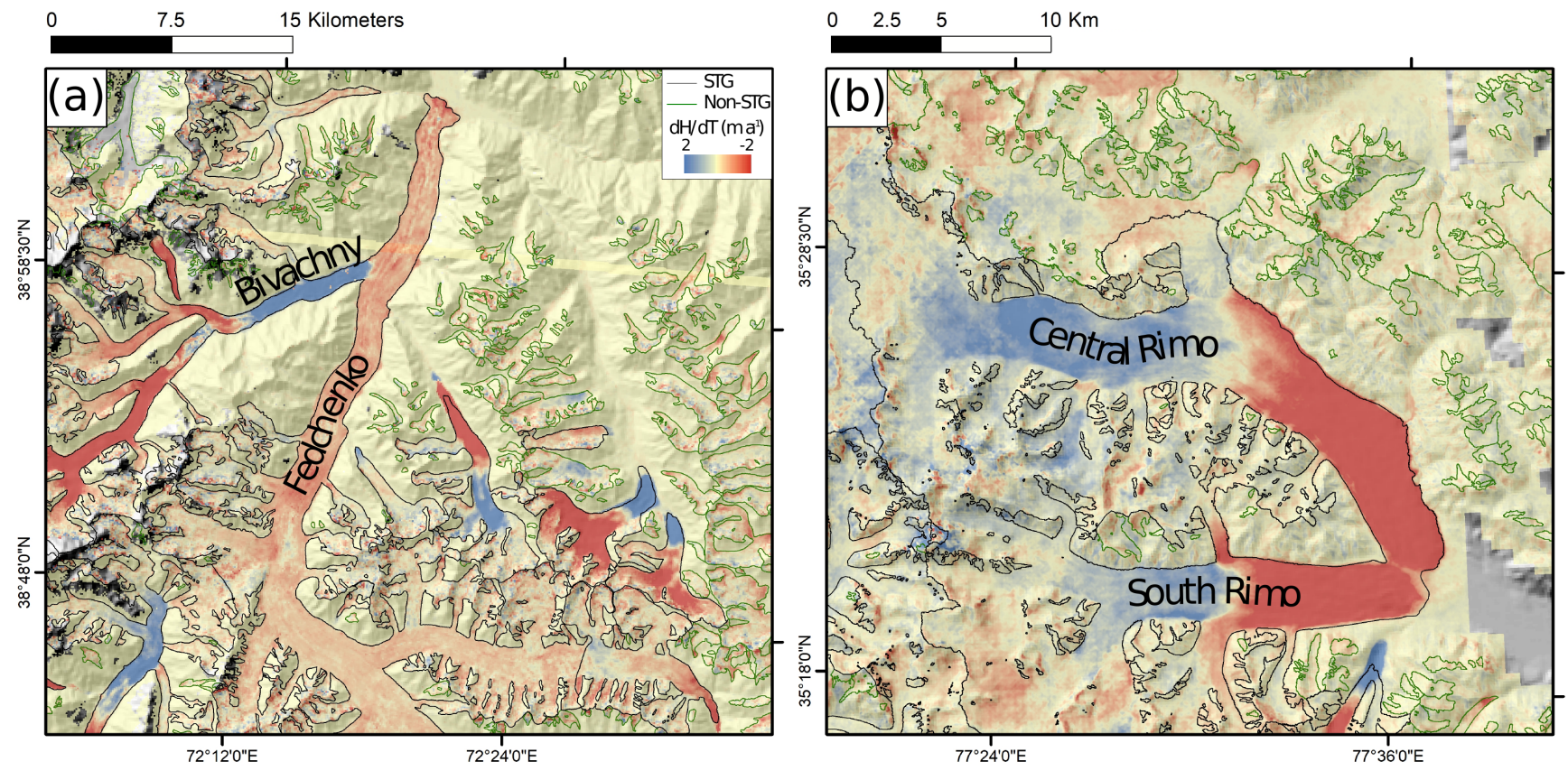

Figure 1. Examples of surface elevation change data used to identify surge-type glaciers. A) Ice mass transfer associated with the surges of Bivachny Glacier, and other local glaciers, over the period 2010-2020 (data from Hugonnet et al., 2021). B) Ice mass build-up in the reservoir zones of Central and South Rimo Glaciers over the period 2000-2018 (data from Shean et al., 2020). Glacier outlines are from the Randolph Glacier Inventory V6.0 (RGI V6.0) (Consortium et al., 2017)

glacier's surge cycle. We also aimed to identify glaciers which exhibited substantial and widespread reservoir zone thickening and concomitant terminal thinning, which we attribute to quiescent phase ice build-up occurring alongside post-surge phase ice loss at lower elevations (Figure 1 (B)). To identify the mass displacement associated with the active phase of a glacier's surge cycle, or substantial ice mass build up associated with the quiescent phase of the surge cycle, we examined multi-temporal datasets of surface elevation change $(\mathrm{dH})$ over HMA glaciers. We primarily used the dH data generated by Shean et al. (2020), which covers the period 2000-2018, to identify the elevation change patterns described above. To aid the identification of surge-like behaviour which may have occurred at the beginning of the period covered by Shean et al. (2020), the signal of which may have been obscured by subsequent long-term thinning, we also examined dH data generated by Hugonnet et al. (2021) over the periods 2000-2005 and 2005-2010, and by Brun et al. (2017) over the period 2000-2016. Distinctive surface elevation patterns were identified manually and corroborated by multiple users.

\subsection{Glacier surface velocity}

The NASA MeaSUREs ITS_LIVE project (Gardner et al., 2019) provides measurements of glacier surface velocity at monthly to yearly temporal resolution over all major land ice regions. Glacier surface velocities are estimated over the 1985-2018 period 
https://doi.org/10.5194/tc-2021-303

Preprint. Discussion started: 6 October 2021

(c) Author(s) 2021. CC BY 4.0 License.

(c) (i)

from Landsat 4,5,7 and 8 images using the auto-RIFT feature tracking algorithm (Gardner et al., 2018). As a consequence of unequal data quality and scarcity in the years covered by the earlier Landsat data archives, we only considered yearly glacier surface velocity derived from Landsat 7 and 8 imagery, between 2000 and 2018, which also matches the period covered by surface elevation change datasets.

The ITS_LIVE yearly glacier surface velocity data are provided with an associated error map. From the collection of yearly glacier surface velocity and their respective error maps, we then form $V_{0}$, the error-weighted mean velocity map for the study period, as follows:

$110 V_{0}=\frac{\sum_{i=1}^{n} w_{i} V_{i}}{\sum_{i=1}^{n} w_{i}}$

where $V_{i}$ is the glacier surface velocity dataset for year $i$ and the weights $w_{i}$ are defined as:

$w_{i}=\frac{1}{\epsilon_{i}^{2}}$

with $\epsilon_{i}$ being the error map for year $i$.

The yearly map of velocity change $(d V)$ is computed as the difference between $V_{0}$ and $V_{i}$ for each year $i$. We then follow the method from Mouginot and Rignot (2015) and eliminate potential outliers using a 3x3 median filter.

From these data, we aim to identify positive velocity anomaly with a magnitude commensurate to that of a glacier surge. We thus assume the distribution of $d V$ to be a 0-mean Gaussian distribution for glaciers with stable flow over the studied period (Figure 2 (a)). Surging behaviour typically displays more complex patterns and one can expect the distribution of surface velocity variations to be either positively (during the active phase) or negatively (quiescent phase) heavy-tailed (Figure 2 (b)). In the present work, we aim to identify glaciers displaying strong positive heavy-tails resulting from active surges on particular years. We thus compute the range between the median $\left(P_{50}\right)$ and the percentile $95\left(P_{95}\right)$ for each glacier and year :

$\mathrm{IPR}_{i}=\left|P_{95 i}-P_{50 i}\right|$

where $\mathrm{IPR}_{i}$ is the inter-percentile range for year $i$. From Equation 3, we propose to quantify surge magnitude as a surge index, defined as follows:

$125 s_{i}=\frac{\mathrm{IPR}_{i}}{k * V_{0}}$

where $s_{i}$ is the surge index for year $i . k$ corresponds to a threshold for surge identification. Surge velocities are usually described as 10 to 1000 times greater than "standard" glacier velocity (Cuffey and Paterson, 2010; Jiskoot, 2011). However, surges in HMA have been documented with surface velocities close to 4 times the standard velocity (Quincey et al., 2011, 2015; Bhambri et al., 2017; King et al., 2021). Thus, we here work with $k=4$.

In practice, a glacier is defined as surge-type when it presents at least one occurrence of $s_{i}>=1$ within the whole study period. Equation 4 allows to quantify the relationship between the observed velocity anomaly for each specific year, and $V_{0}$. We thus highlight variations in the magnitude of the active phase of surge events from one year to another. 
(a)
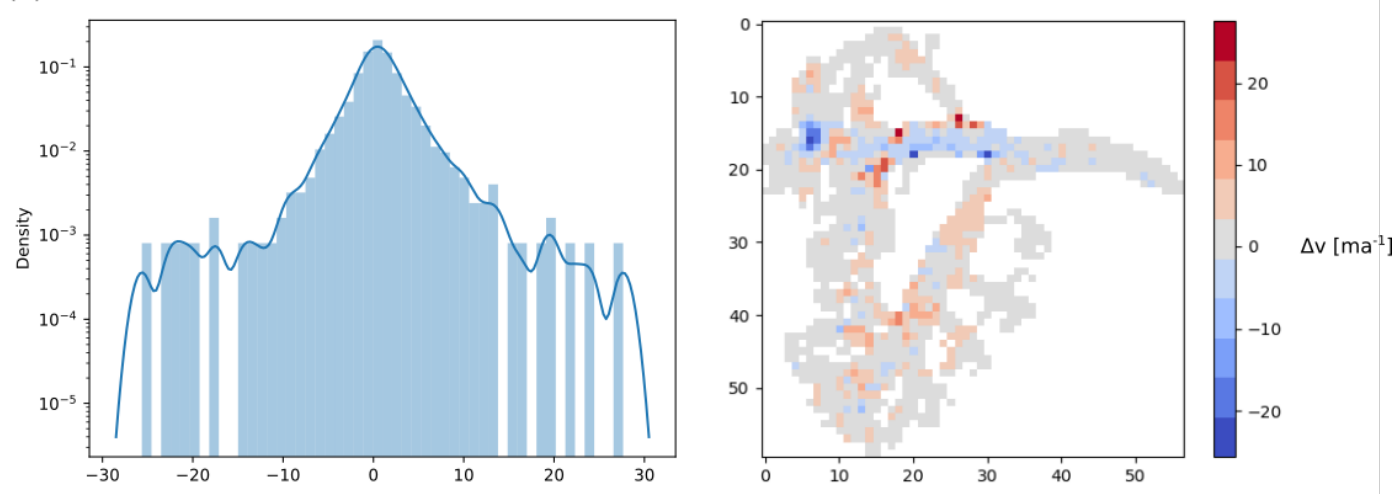

(b)
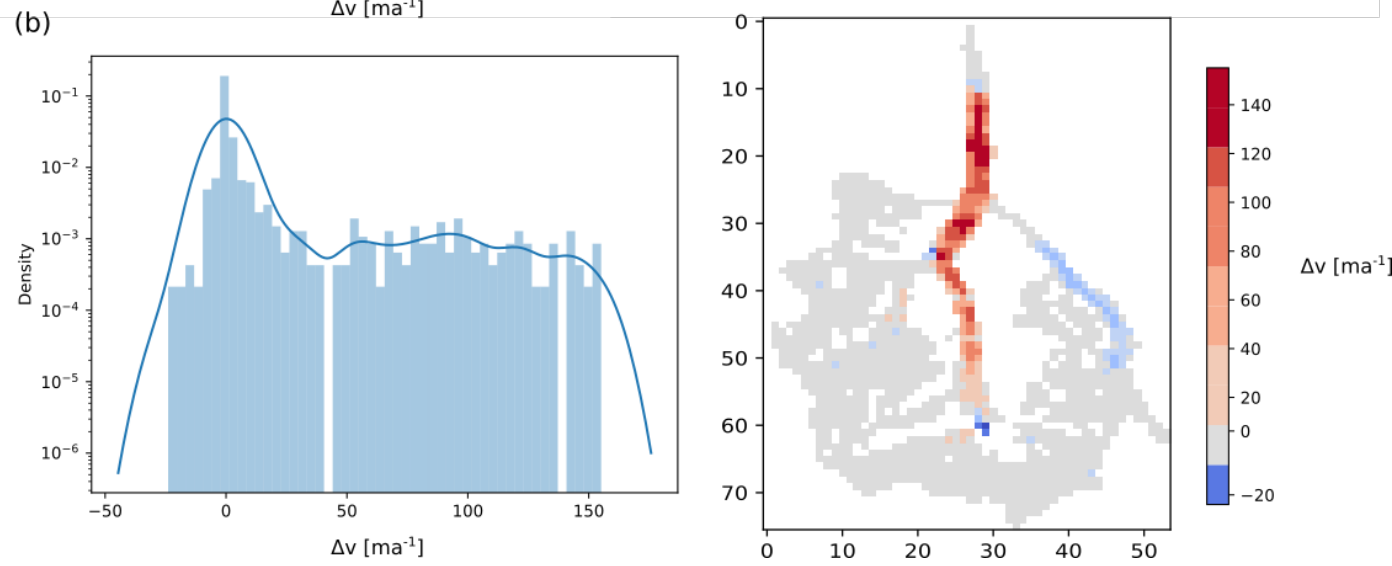

Figure 2. Distribution and map of $d V$ for two glaciers. (a) Samudra Tapu glacier, Chandra River Basin, Western Himalaya. Note the symmetrical $d V$ distribution. (b) K2 North Glacier complex, Karakoram. Note the positive heavy tail on $d V$ as a consequence of surging behaviour.

\subsection{Glacier surface features}

Substantial changes occur in the stress and strain regime at the surface of a surge-type glacier during its active phase which result in the widespread modification of surface structures such as crevasse patterns (Jennings and Hambrey, 2021). Such changes in structural glaciology have previously been used to identify glacier surging (See Grant et al. (2009); Lovell et al. (2018) for example).

We performed systematic visual checks for the presence and temporal variation of diagnostic crevasse patterns on Very High

Resolution (VHR) optical imagery. We used multi-temporal, VHR imagery in Google Earth (GE) and additional images in Bing maps to confirm or infirm the identification of surge-type glaciers, alongside glacier surface elevation and velocity changes. We aimed to identify crevasse patterns indicative of longitudinal extension or lateral shear margins, which are indicative of ice flow increases and ice mass redistribution in the down-glacier direction (Figure 3). The availability of VHR optical imagery allowed for the examination of structures in glacier reservoir and receiving zones, whereas moderate resolution optical imagery 
https://doi.org/10.5194/tc-2021-303

Preprint. Discussion started: 6 October 2021

(c) Author(s) 2021. CC BY 4.0 License.

(c) (i)

(Landsat, for example) typically only allows for the identification of larger glacier features such as looped moraines, which might not be prevalent on all surge-type glaciers

\subsection{Glacier outlines and tributary glacier surges}

In this study, we used the Randolph Glacier Inventory (RGI) V6.0 glacier outlines (Pfeffer et al., 2014; Consortium et al., 2017). The RGI provides a snapshot of glacier extent near the beginning of the 21 st century and so current glacier extent, particularly of glaciers which have since surged, may differ somewhat from the area estimates associated with the RGI. However, such differences are unlikely to cause erroneous comparisons at a regional level and we have not further modified RGI glacier extents in order to compare the attributes of surge-type glacier clusters in different parts of HMA.

Similarly, the RGI does not propose individualized polygons for tributary glaciers within larger glacier complexes. Any statistical analysis specifically studying spatial quantities of individual glaciers (surface area for example) from an RGI-based surge-type glacier inventory can therefore be biased by the presence of tributary glacier surges in wider, non-surge-type glacier complexes. Prominent examples of this phenomenon are Bivachny glacier (Fedchenko glacier complex, Pamir, Tajikistan), Maedan glacier (Panmah Glacier, Karakoram, Pakistan) and Liligo glacier (Baltoro Glacier, Karakoram Pakistan) (Wendt et al., 2017; Goerlich et al., 2020; Hewitt, 2007; Belo et al., 2008).

In the present study, we manually digitized the maximal surface area of surge-affected zones within glacier complexes observed between 2000 and 2018. Surge-affected areas are delineated from the extent of substantial glacier surface elevation change caused by ice mass transfer during the active phase of a surge, using very-high resolution optical imagery from Google Earth and Bing maps to corroborate each delineation. We therefore provide an estimate of the maximum surface area affected by surges $(n=300 / 666)$, in addition to the positively-biased surface area of surge-type RGI polygons. Due to the relatively low resolution (size of one pixel on the ground) of the velocity data used in this study (240m, see Section 2.2), we follow the method proposed by Dehecq et al. (2019) and only consider RGI polygons with an area greater than $5 \mathrm{~km}^{2}$ for velocity-based analyses.

\subsection{Identification of surge-type glaciers}

We carried out a preliminary manual search of surface elevation change datasets to highlight possible surge-type glaciers by identifying typical surge-induced surface elevation change patterns (see Section2.1) which contrasted directly with local thinning patterns evident on non-surge-type glaciers. In parallel, automatic surge detection was carried out from the ITS_LIVE datasets on RGI polygons with an area greater than $5 \mathrm{~km}^{2}$. Two sub-inventories were thus created before being merged together. Each glacier was then individually inspected for the presence of surface features typical of active surging (see Section 2.3). To be qualified as surging, individual glaciers must display at least 2 of the 3 proposed identification criteria. By combining different criteria, we typically mitigate false identification of phenomena other than surges which may cause a similar signal in, for example, surface velocity data such as lake-terminating glacier frontal speed-up. The multi-factor approach also mitigates problems such as remnant noise in the surface elevation and velocity datasets among others. 
https://doi.org/10.5194/tc-2021-303

Preprint. Discussion started: 6 October 2021

(C) Author(s) 2021. CC BY 4.0 License.

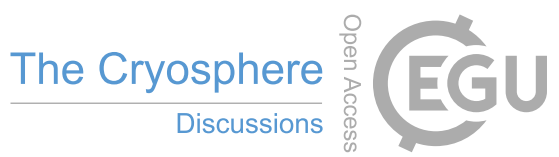

(c) (i)

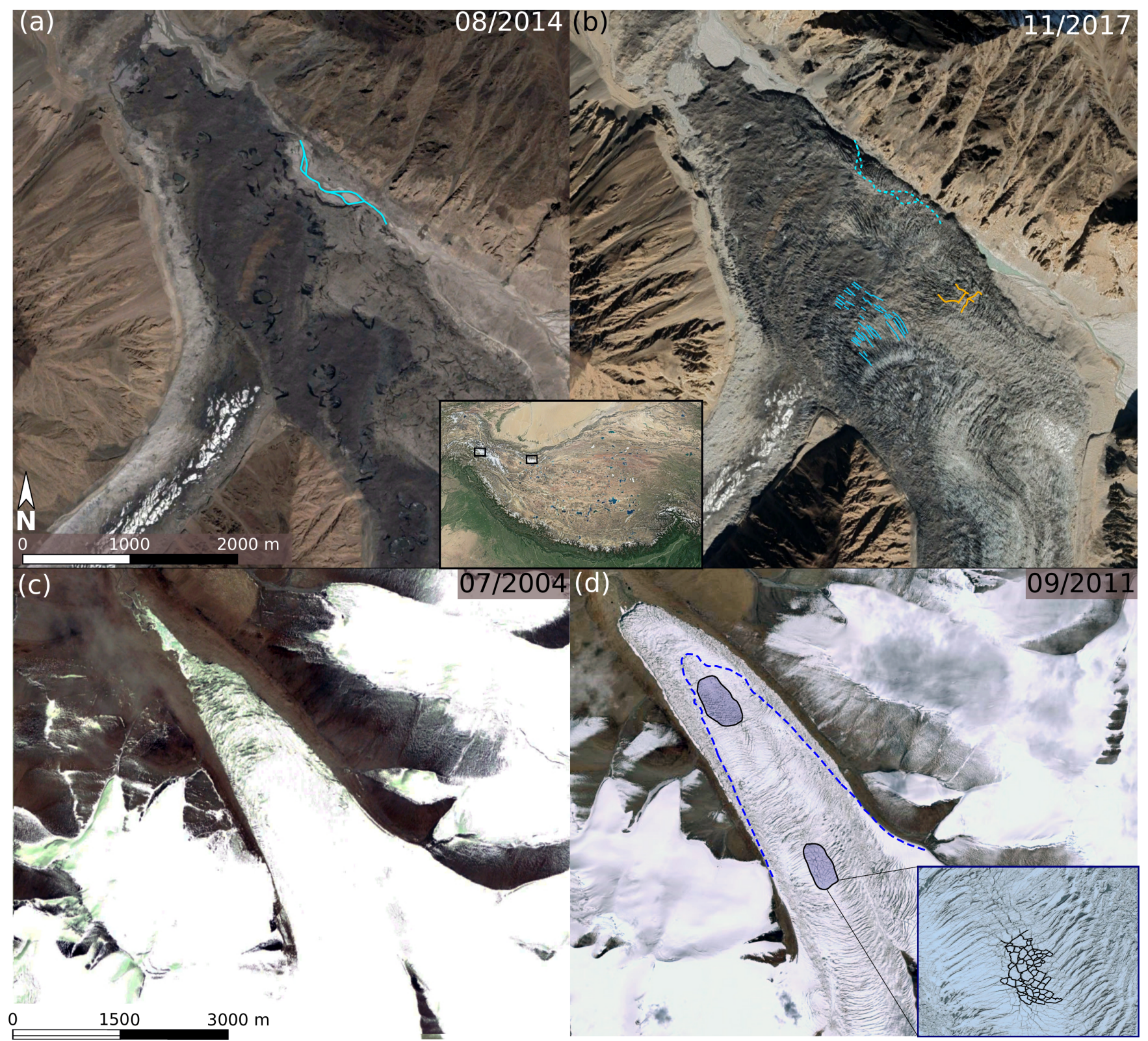

Figure 3. Google Earth imagery close ups of surface features indicative of surges on debris-covered (Top row: 2017 surge of Khurdopin glacier, Hunza Basin, Karakoram) and clean ice glaciers (Bottom row: 2008-14 surge of N2 glacier, West Kunlun Tibet). (a) Khurdopin glacier in August 2014 during the quiescent phase. Note the abundance of supraglacial ponds on the stagnant ice. Blue line : river bed. (b) Khurdopin glacier in November 2017 during the active phase (peaking in May 2017). (Steiner et al., 2018). The surface is heavily crevassed with longitudinal (blue lines) and intersecting crevasses (yellow). The blue dashed line represents the location of the river bed in panel (a). (c) N2 glacier in a quiescent phase in 2004. (d) N2 glacier in 2011 after active phase peak (August 2009-November 2010) (Yasuda and Furuya, 2015). The blue dashed line represents the position of glacier terminus in 2004. Note the substantial terminus advance and the two zones (blue polygons) of rhomboic crevasse patterns, indicative of surge-type behaviour (Christina Herzfeld and Zahner, 2001; Herzfeld et al., 2004). (c) Google Earth 2021 and (c) Microsoft. 
https://doi.org/10.5194/tc-2021-303

Preprint. Discussion started: 6 October 2021

(c) Author(s) 2021. CC BY 4.0 License.

(c) (i)

\begin{tabular}{|c|c|c|c|c|c|}
\hline HIMAP region & N STGs & N Glaciers & Area of STGs $\left(\mathrm{km}^{2}\right)$ & Area of all glaciers $\left(\mathrm{km}^{2}\right)$ & STG area $(\%)$ \\
\hline Karakoram & 223 & 11586 & 9736 & 21475 & 45.3 \\
\hline Western Pamir & 173 & 9118 & 2883 & 8480 & 33.9 \\
\hline Eastern Pamir & 47 & 1609 & 784 & 2200 & 35.6 \\
\hline Pamir Alay & 2 & 3151 & 26 & 1846 & 1.4 \\
\hline Central Tien Shan & 54 & 5836 & 1629 & 7270 & 22.4 \\
\hline Northern/Western Tien Shan & 19 & 3903 & 173 & 2261 & 7.7 \\
\hline Eastern Tien Shan & 1 & 4259 & 3 & 2333 & 0.1 \\
\hline Western Kunlun Shan & 60 & 5674 & 2096 & 8456 & 24.8 \\
\hline Eastern Kunlun Shan & 13 & 3092 & 485 & 2994 & 16.2 \\
\hline Tibetan Interior Mountains & 19 & 3493 & 372 & 3815 & 9.8 \\
\hline Tanggula Shan & 14 & 1584 & 318 & 1840 & 17.3 \\
\hline Eastern Hindu Kush & 9 & 4375 & 193 & 3051 & 6.3 \\
\hline Qilian Shan & 9 & 2684 & 68 & 1597 & 4.3 \\
\hline Central Himalaya & 7 & 7374 & 55 & 8986 & 0.6 \\
\hline Western Himalaya & 6 & 9951 & 136 & 8117 & 1.7 \\
\hline Eastern Himalaya & 1 & 2963 & 9 & 2983 & 0.30 \\
\hline Altun Shan & 3 & 467 & 16 & 295 & 5.4 \\
\hline Eastern Tibetan Mountains & 3 & 522 & 35 & 312 & 11.2 \\
\hline Nyainqentanglha & 2 & 7417 & 16 & 7046 & 0.2 \\
\hline Gangdise Mountains & 1 & 3851 & 11 & 1270 & 0.9 \\
\hline Hengduan Shan & 0 & 2056 & 0 & 1281 & 0 \\
\hline Dzhungarsky Alatau & 0 & 968 & 0 & 520 & 0 \\
\hline Total/Mean* & 666 & 95536 & 19044 & 97605 & $19.5^{*}$ \\
\hline
\end{tabular}

Table 1. Table of number and proportion of area covered by RGI polygons of surge-type glaciers for each HIMAP region (Bolch et al., 2019). STG: surge-type glacier

\section{Results}

Out of the $\approx 95000$ glaciers in HMA, 666 have displayed surge-type behavior between 2000 and 2018 (Figure 4). Traditional surge-type glacier clusters are clearly defined, as approximately two thirds of the identified surge-type glaciers are located in the Karakoram (223) or in the Pamirs (223) (Table 1). Smaller clusters are located in the Tien Shan and the Kunlun Shan, whilst isolated and less numerous examples are found across the Tibetan plateau and it's peripheral mountain ranges (Table 1). 


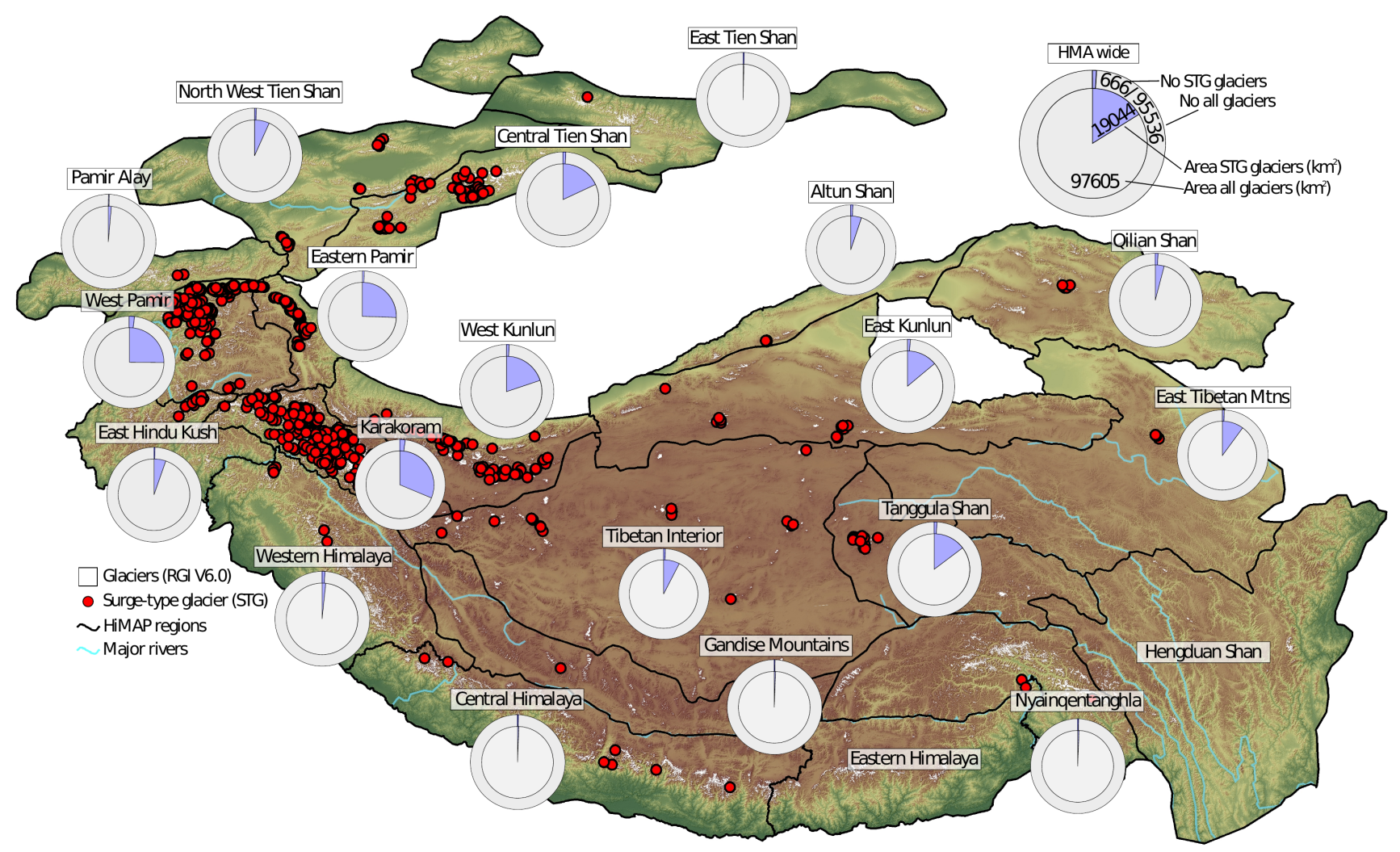

Figure 4. The distribution of surge-type glaciers (red dots) across HMA, identified by our multi-factor remote sensing approach. The number and area of surge-type glaciers within each HIMAP region (Bolch et al., 2019), compared to the total glacier population, are also shown. Prominent but well known clusters of surge-type glaciers are evident in the Pamirs and Karakoram, but our analyses has also detected smaller clusters of surge-type glaciers across the Tibetan Plateau and Tien Shan.

From the 666 identified glaciers, 68 had been previously identified as "Observed Surging" in the RGI V6.0. We further confirm 107 glaciers, previously identified as "Probable" or "Possible" surge-type glaciers. Finally, we newly identify 491 glaciers, previously categorized as "No Evidence" and "Not Assigned". RGI polygons of surge-type glaciers cover a total surface area of $19044 \mathrm{~km}^{2}$, which corresponds to $\approx 19.5 \%$ of the glacierized area in HMA. Unsurprisingly, surge-type glaciers account for the greatest portion of RGI glacier area in the Karakoram (45.3\%), followed by the Eastern (33.9\%) and Western Pamir (35.6\%) (Figure 4 and Table 1). Surge-type glaciers account for less than $1 \%$ of glacier area in 9 of the 22 HIMAP (Bolch et al., 2019) regions. We find no evidence of glacier surging in the Hengduan Shan or Dzhungarsky Alatau.

\subsection{Distribution and geometry of surge and non surge-type glaciers}

Previous studies have demonstrated significant differences in glacier geometry (e.g. length, slope) between surge-type and non surge-type glaciers (see Sevestre and Benn (2015) among others, for example). We here further document the impact of 
https://doi.org/10.5194/tc-2021-303

Preprint. Discussion started: 6 October 2021

(C) Author(s) 2021. CC BY 4.0 License.

(c) (i)

geometry on surge behaviour by studying glacier elevation range, slope, length area and aspect, using attributes derived from the RGI V6.0. Note that, due to the wide ranges covered by each attribute, we compare common logarithm values.

Throughout HMA, surge-type glaciers systematically present greater elevation range and area (Figure 5). Given the high correlation between the studied geometrical parameters, such a pattern is unsurprising. We further observe generally shallower slopes for surge-type glaciers than non-surge-type glaciers. The difference is not as clear cut as for the other parameters; the median surge-type glacier slope indeed lies within one standard deviation of the median for non-surge-type glaciers. Slope alone is thus not a sufficient predictor for surge-type behavior in HMA. We however observe that the frequency of surge-type glaciers drastically increases with greater lengths and shallower slopes (Figure 6), as predicted by the enthalpy balance theory (Benn et al., 2019).

While in the Tien Shan, Pamirs and Kunlun Shan, aspect distributions do not significantly differ, we nonetheless note narrower distributions and increased number in south quadrants for surge-type glaciers, with $\approx 8 \%$ of glaciers flowing $\mathrm{S}$ in the Tien Shan, $\approx 7 \%$ flowing SW and S in the Pamirs and $\approx 9 \%$ flowing SE in the Kunlun Shan $(\approx 2 \%$ for non-surge-type glaciers in all three regions) (Figure 7). We note distinct variability in the aspect distribution of surge-type glaciers in the Tibetan Mountains (Figure 7), which show no dominant orientation. Inter-regional differences in glacier type (defined in the RGI V6.0) reflect and possibly explain the aforementioned variability in glacier aspect. Topographically confined mountain glaciers are most common in regions with coherent surge-type glacier aspect (Figure 8), whereas regions with larger numbers of ice cap outlet glaciers show more variability in surge-type glacier aspect (Figure 7). Indeed, the number of outlet surgetype glaciers outweighs the number of surge-type mountain glaciers in the Tibetan Mountains, where there is no clear aspect preference of surge-type glaciers.

\subsection{Analysis of glacier geometry and its impact on surge-type behaviour}

We here further document the potential impacts of geometry on surging behaviour, both at HMA and regional scales. More specifically, we study the relationships between surge-affected area in glacier complexes and median surge indices with glacier median elevation, elevation range, slope and length. We observe no particular relationship between the area affected by surge in glacier complexes and the median elevation or the slope (Figure 9). Similarly no evident correlation can be described between the median surge index and the same geometric attributes. The common logarithm of the surge-affected area in glaciers complex is however strongly linearly correlated (Pearson's $\mathrm{R}=0.81, p$-value $<0.001$, zero-mean residuals) to that of maximum glacier complex length. This linear correlation of the common logarithm of two variables yields a power law relationship between the surge-affected area and the maximum length of glacier complexes, with a power law exponent of 1.3 . We further identify similar linear relationships between the common logarithms of the median surge index and the elevation range (Figure 9) (Pearson's $\mathrm{R}=0.59, p$-value $<0.001$, zero-mean residuals), with a power law exponent close to 0.84 .

On a regional scale, the Tien Shan, Pamirs and the Karakoram all show relatively high correlation between range and median surge index with statistically significant p-values. We note an important anti-correlation between slope and surge area in the Kunlun which is a consequence of contrasting glacier geometries in the Kunluns. While the distribution of glacier slopes in the Karakoram and the Pamirs (for example) present a uni-modal distribution with respective means close to 25 and 22 degrees, 

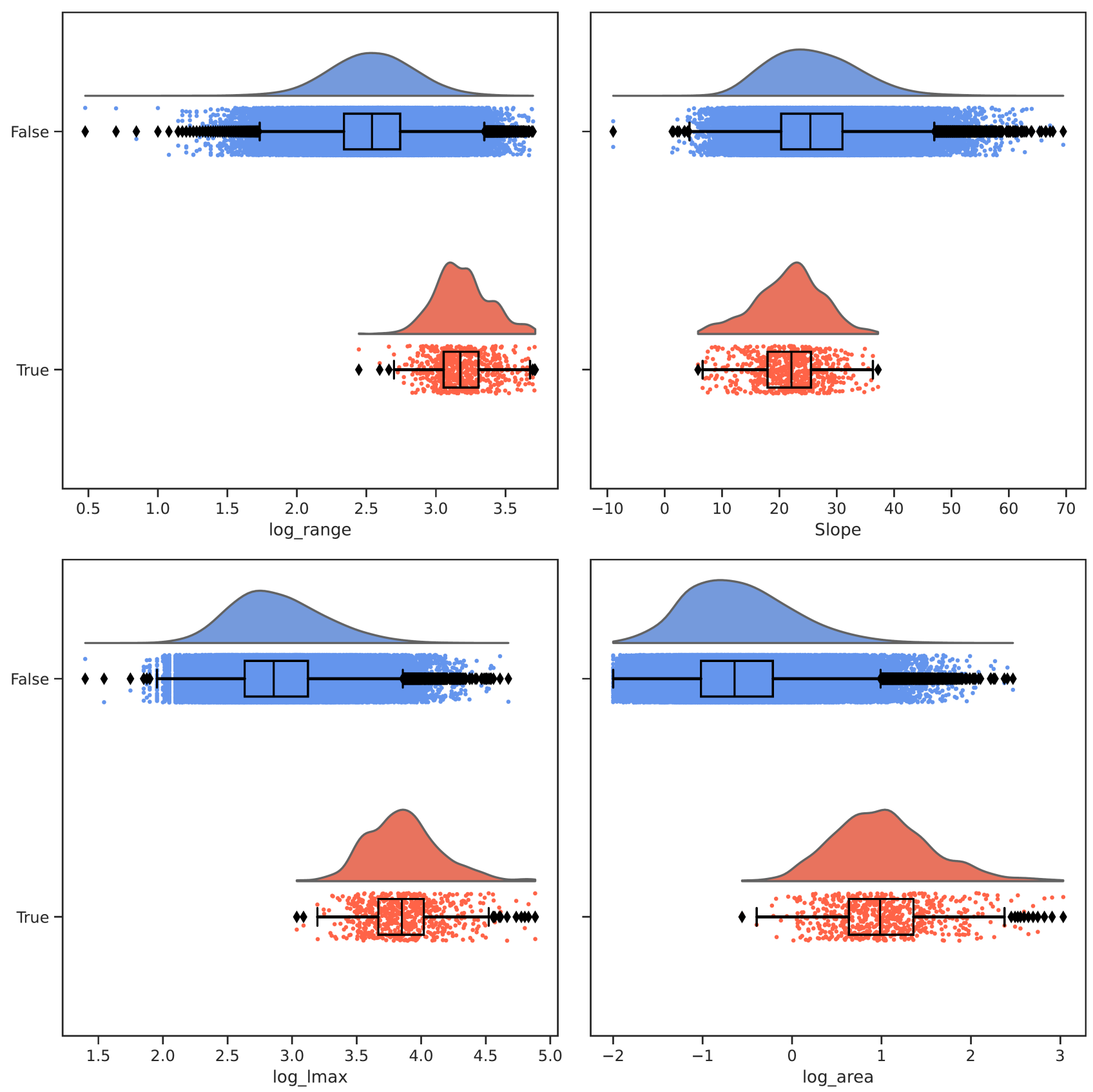

Figure 5. Distributions of geometrical attributes between non-surging and surge-type glaciers. Surge-type glaciers are represented in orange, non surge-type glaciers in blue. Lmax is the length of the centerline of the longest glacier trunk of each RGI polygon. Area, length and altitude range are represented using common logarithms. Whiskers represent the 95th percentile of each distribution while limits of the box represent 1 standard deviation. 
https://doi.org/10.5194/tc-2021-303

Preprint. Discussion started: 6 October 2021

(c) Author(s) 2021. CC BY 4.0 License.

(c) (i)

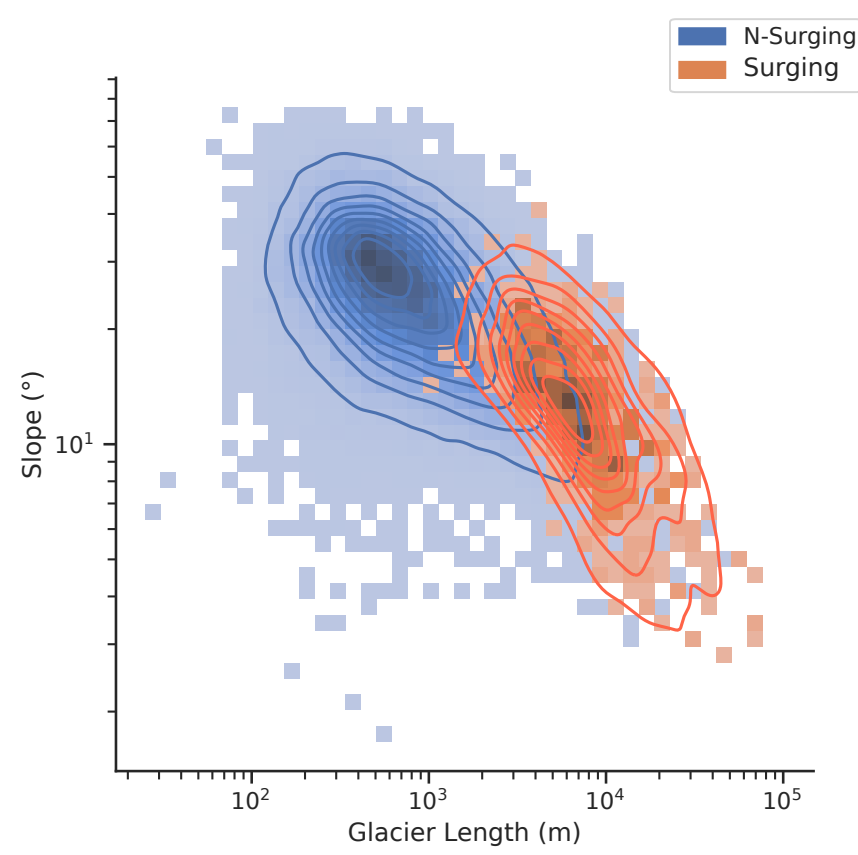

Figure 6. Length and mean slope for surging and non-surge-type glaciers in HMA. Due to the disparity in sample sizes between surge-type (666) and non surge-type glaciers (more than 90000), the length/mean slope relationship is represented using a bi-variate histogram. Contour lines represent an estimate of the probability density, approximated using kernel density estimation.

slope distribution in the Kunlun is uniform with no clearly identifiable mode. All identified correlations display a heavy scatter and more data is needed to consolidate these relationships.

\subsection{The impact of surge-type behaviour on glacier mass balance}

The mass balance measurements presented here originate from the studies of Shean et al. (2020) and Hugonnet et al. (2021), covering the periods $2000-2018$ and 2000-2020, respectively.

We observe no major difference between the medians of the different distributions in the Karakoram, Pamirs, Kunlun Shan, Tien Shan and Tibetan Mountains (Figure 10). Median mass losses for surge-type (non surge-type) glaciers are close to -0.2 $(-0.09)$ m.w.e $\mathrm{a}^{-1}$ in the Karakoram, $-0.1(-0.05)$ m.w.e $\mathrm{a}^{-1}$ in the Pamirs and $-0.09(-0.05)$ m.w.e $\mathrm{a}^{-1}$ in the Kunlun

235 Shan. We however note that the mass balance distribution for surge-type (non surge-type) glaciers in the Karakoram is positively (negatively) skewed with $g=1.1(-1.4)$. The mass of the distribution for surge-type (non surge-type) glaciers in the Karakoram is thus concentrated towards more negative (positive) mass balance.

The number of surge-type glaciers reported in Qilian Shan, Eastern Hindu Kush, Himalayas is not considered representative $(<10$ glaciers in each case $)$. 

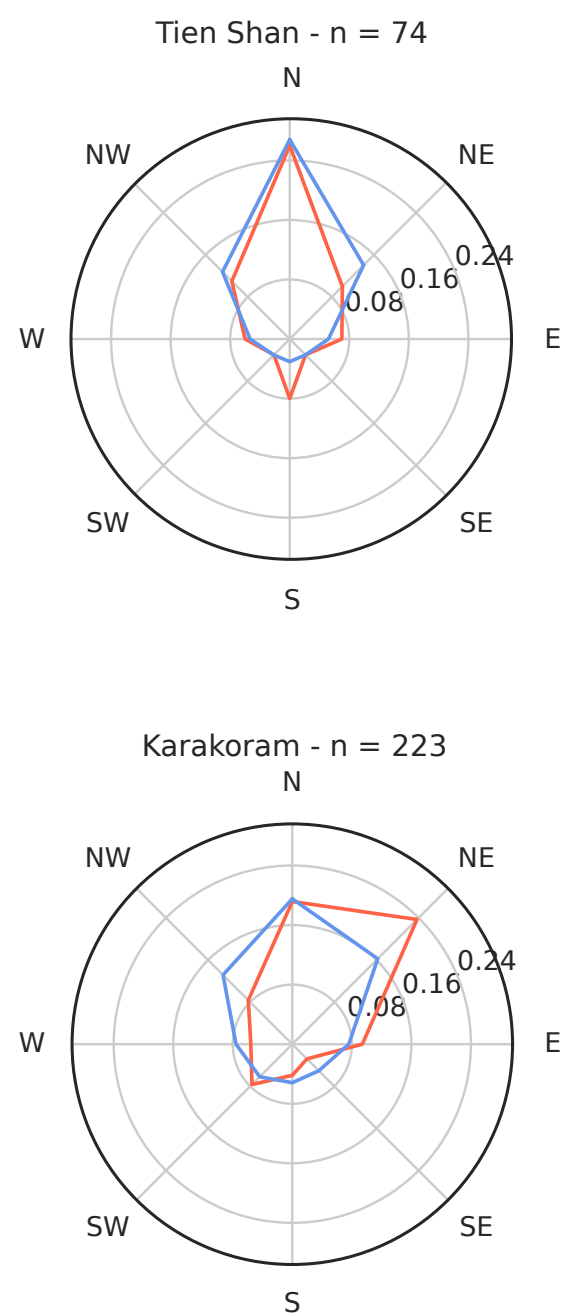

Pamirs $-\mathrm{n}=223$

$\mathrm{N}$

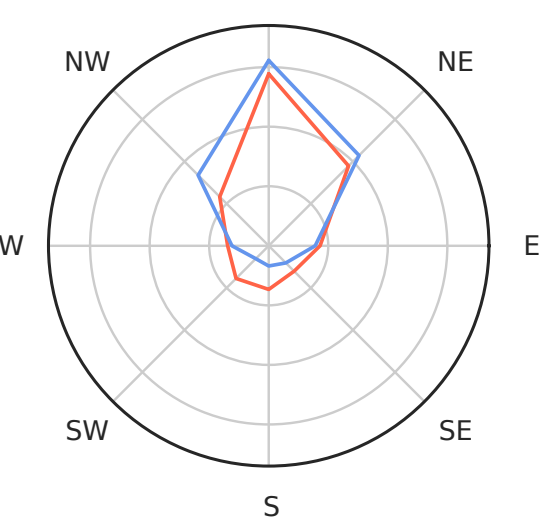

Himalayas $-\mathrm{n}=13$

$\mathrm{N}$

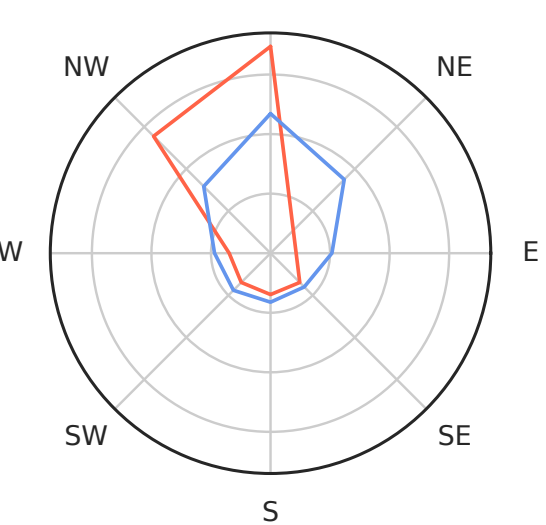

Tibet $-\mathrm{n}=39$

$\mathrm{N}$

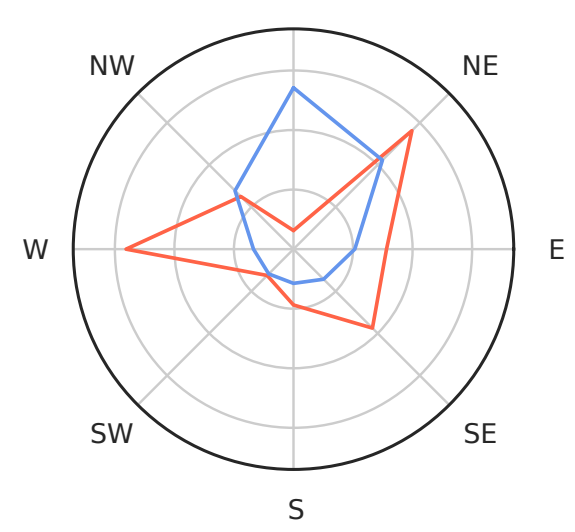

Kunlun Shan $-\mathrm{n}=76$

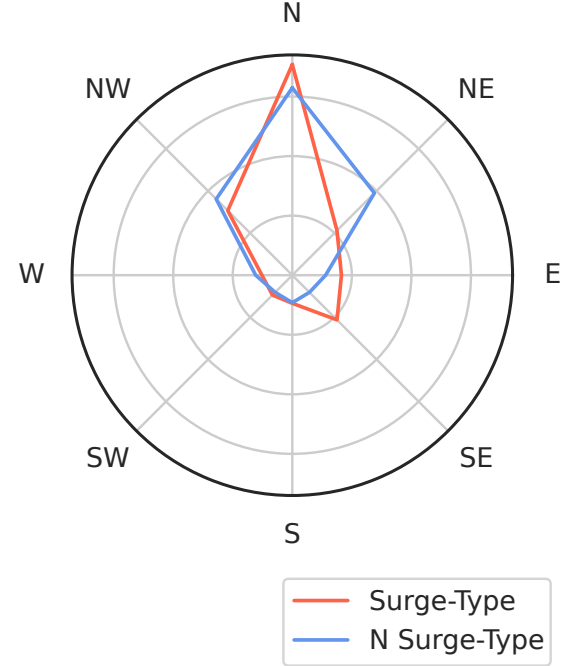

Figure 7. Aspect sector distribution for surging and non surge-type glaciers for each greater study regions per count. $n$ refers to the number of surge-type glaciers per greater HIMAP region. 

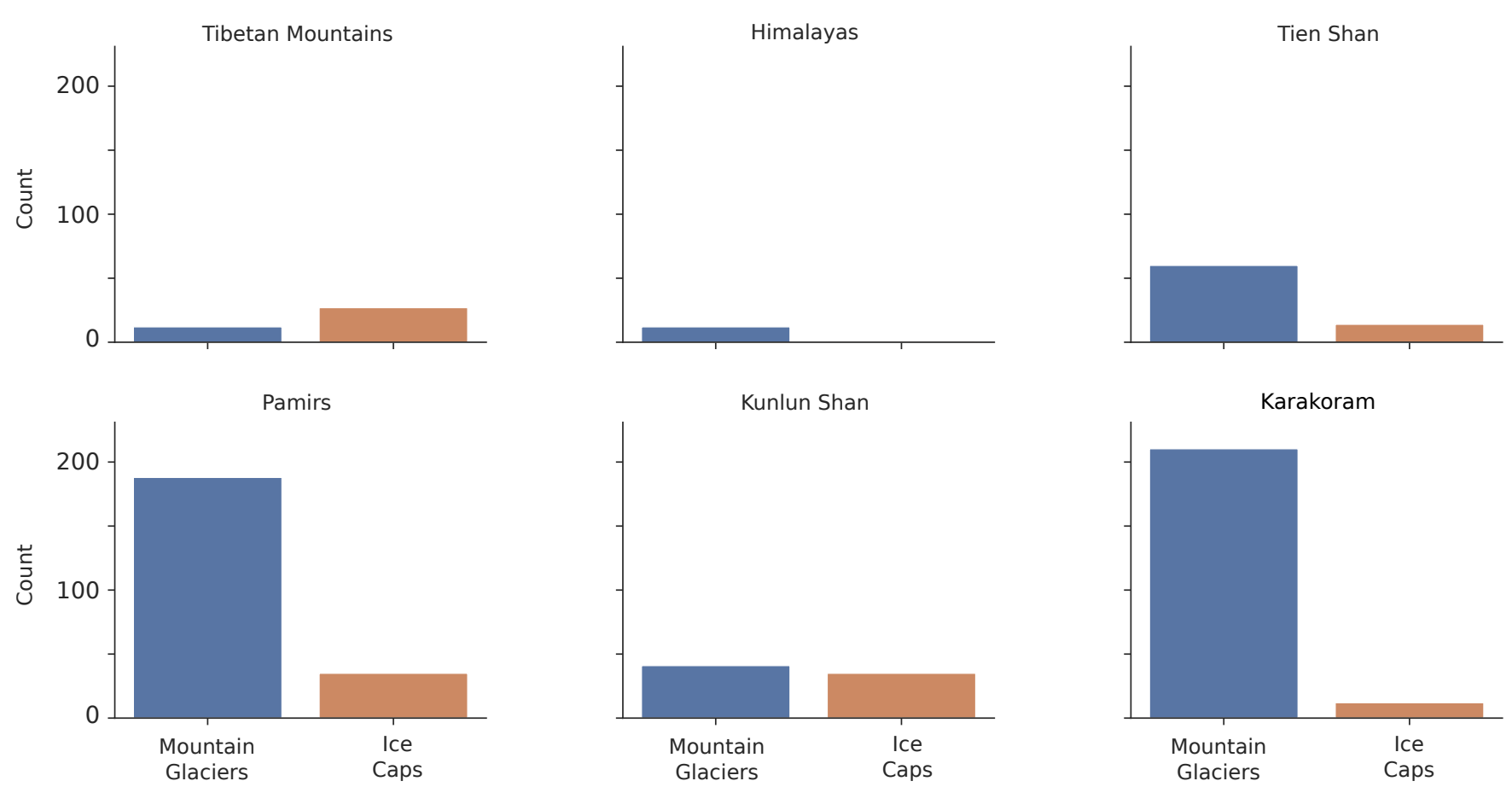

Figure 8. Distributions of surge-type glacier types for each of the greater HIMAP regions. Note that the Tibetan Mountains is the only region where ice cap outlet glacier are more represented than mountain glaciers, with a ratio of 2.7 .

Inspection of the temporally resolved mass balance estimates of Hugonnet et al. (2021) suggests marked changes of glacier mass budgets during their transition from late quiescence to their active surge phase, and then immediately following their latest surge (Table 2). More specifically, Khurdopin glacier displayed balanced and even positive mass balance prior to (20102015) and during the early stages (2015-2016) of its most recent surge. Khurdopin glacier then experienced substantial ice mass loss (-0.22- $-0.3 \mathrm{~m}$ w.e.a) during the later stages of its latest surge and immediately following surge cessation. Similarly, Hispar glacier (not including the Kunyang tributary, which surged itself around 2007) experienced a slight decrease in mass loss between the later stages of quiescence (2010-2012) and the start of its surge phase (2012-2014-Table 2) and then a significant increase in its rate of ice loss once the active phase of the surge had ended. The rate of ice mass loss doubled from Hispar glacier immediately following the end of its 2014-2016 surge.

\subsection{Temporal variability and maximum velocities in surge active phase}

We observe no major differences in the length of the active phase of surges captured by the velocity data in different regions across HMA, the distributions of which are presented in Figure 11 (a) and (b) respectively. While the distributions present similar medians (2, 2, 2.3 and 2.3 for the Tien Shan, Pamirs, Kunlun Shan and Karakoram respectively) and 25th percentile (1.2, 1.3, 1.3 and 1.4), we note a disparity in 75th percentile (2.2, 3.4, 4.4, and 4). For the Pamirs, Kunlun and Karakoram, the inter-quartile range exceeds the median maximum surge index by a factor 1.1-1.3, highlighting the irregularity of surge 

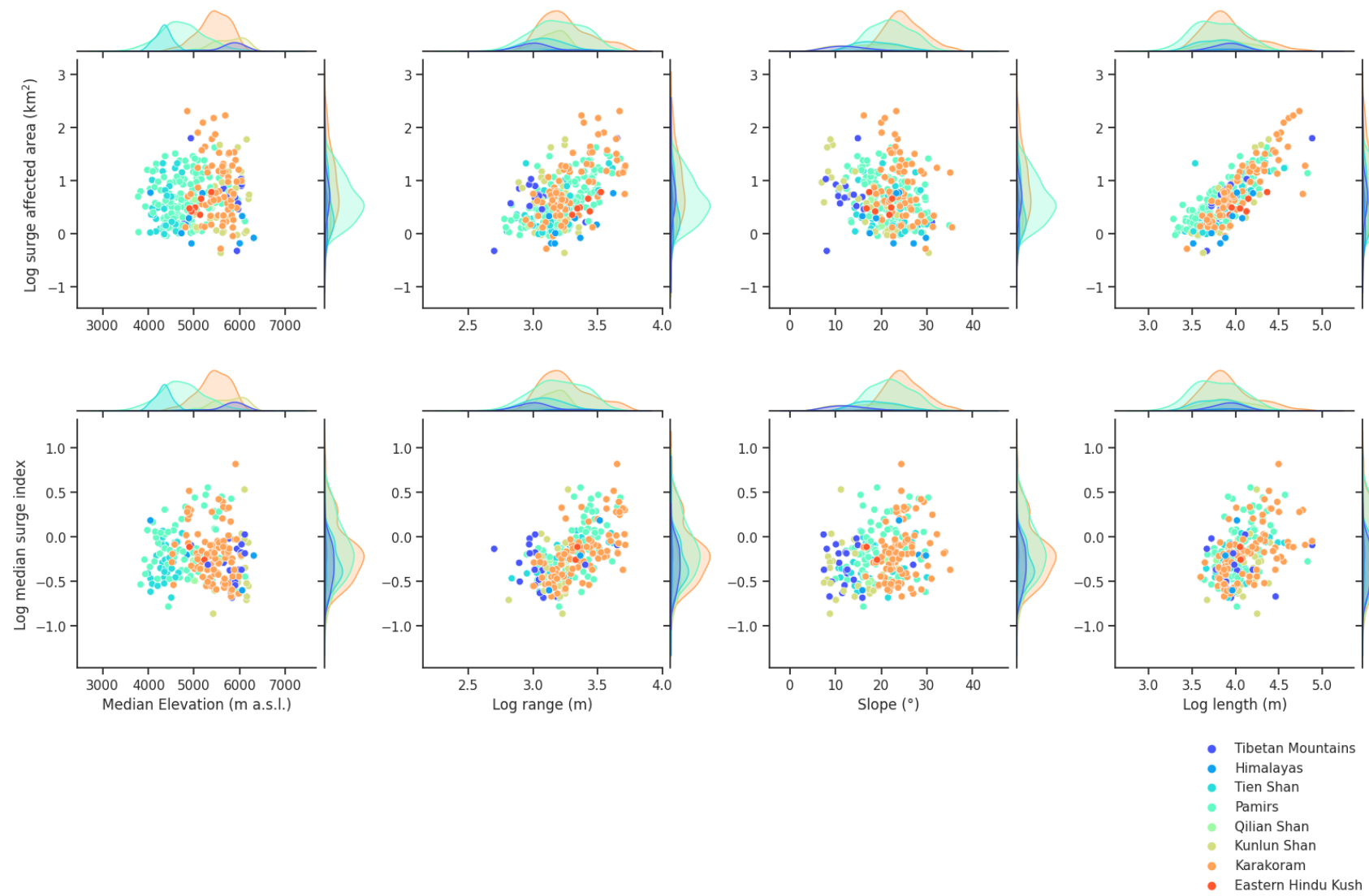

Figure 9. Correlation between the different geometric parameters of surge type glaciers

\begin{tabular}{|c|c|c|c|c|}
\hline Glacier & Quiescence & Build-up & Active phase & Post-surge \\
\hline Khurdopin & $-0.04(2010-2015)$ & $0.17(2015-2016)$ & $-0.22(2016-2017)$ & $-0.3(2017-2018)$ \\
\hline Hispar (main trunk) & $-0.38(2010-2012)$ & $-0.24(2012-2014)$ & $-0.4(2014-2016)$ & $-0.8(2016-2018)$ \\
\hline
\end{tabular}

Table 2. Example of mass balance (m.w.e $\mathrm{a}^{-1}$ ) over specified period and phases in the surge cycles of Khurdopin and Hispar glaciers' last documented surges. For more on the specific surges of each glacier, we refer the reader to Paul et al. (2017); Bhambri et al. (2020); Steiner et al. (2018) 

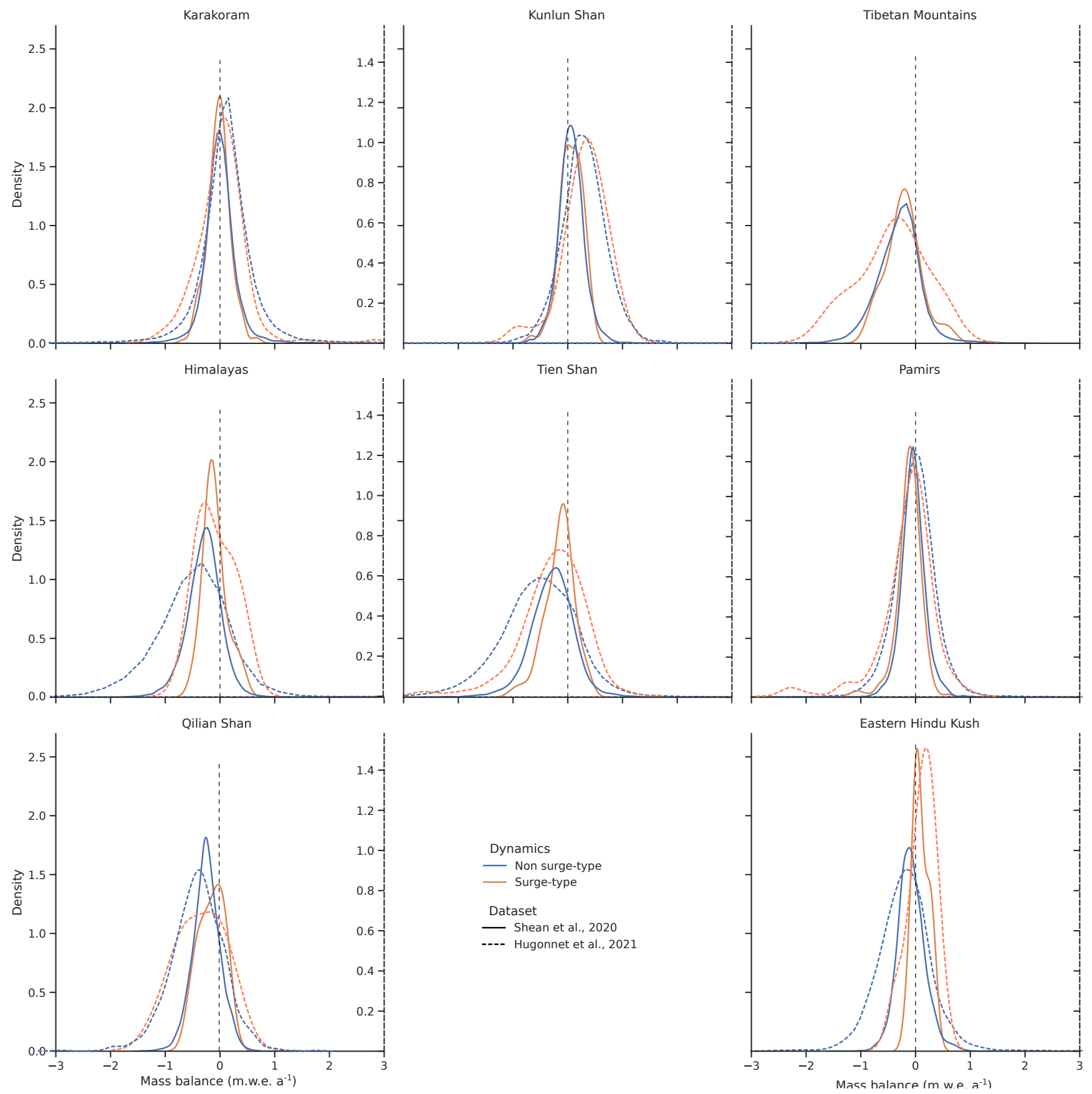

Figure 10. Distributions of mass balance for surge-type and non surge-type glaciers for the greater HIMAP regions derived from the results of Shean et al. (2020) and Hugonnet et al. (2021). 


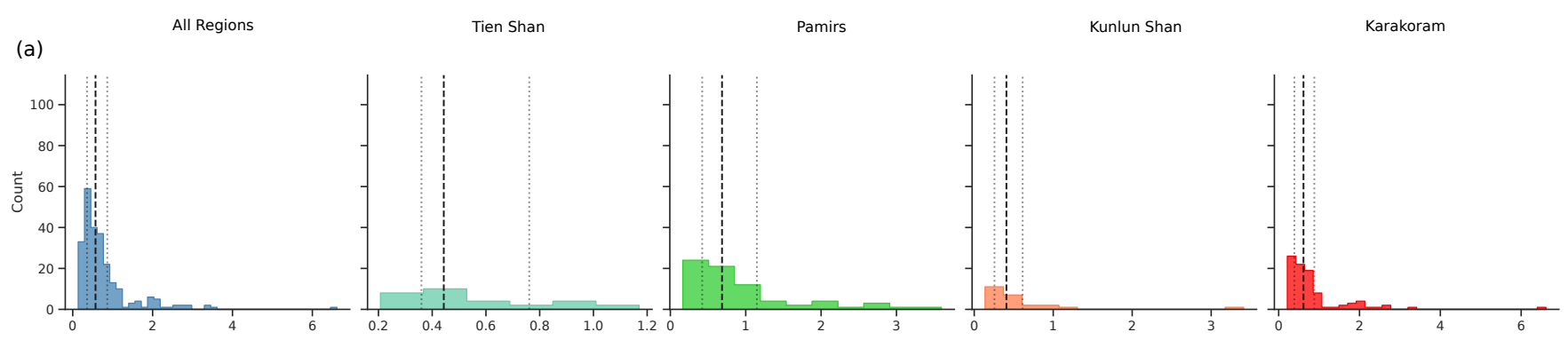

(b)
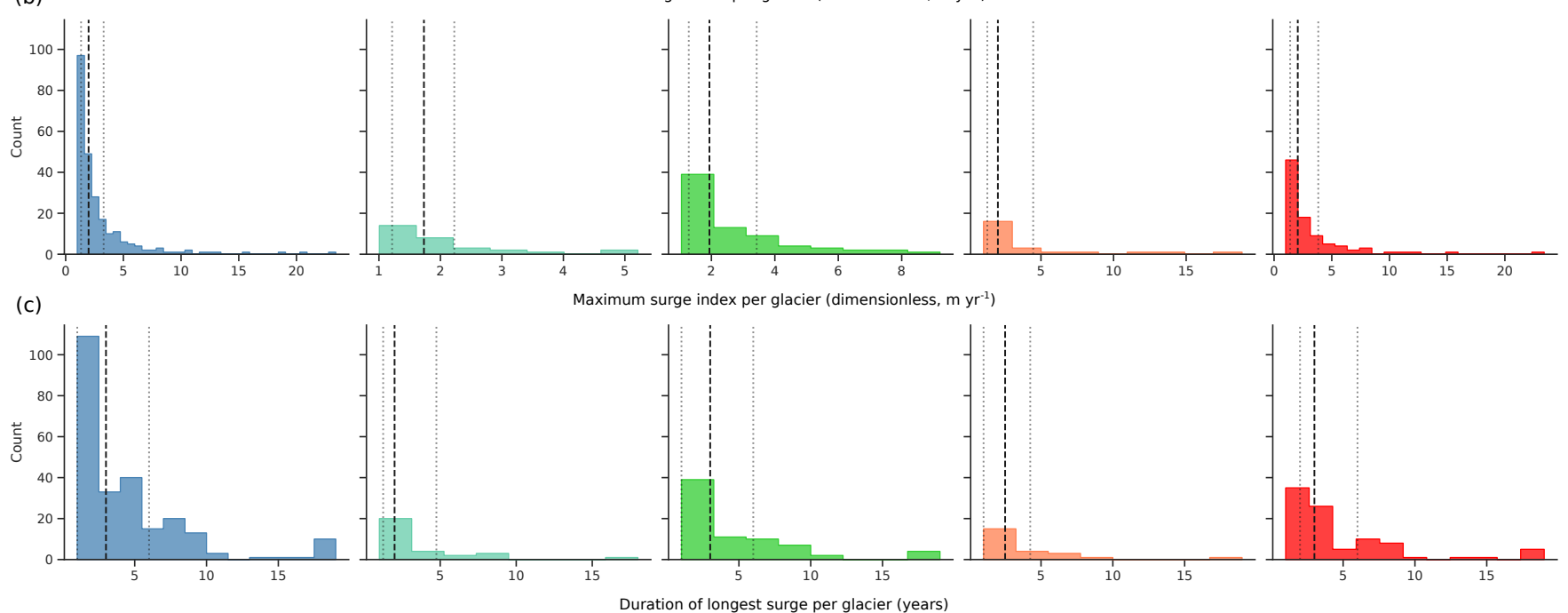

Figure 11. Distribution of (a) Median surge index per glacier, (b) Maximum surge index per glacier and (c) Duration of the longest active phase per glacier for the whole HMA and 4 of the larger HIMAP regions. Dashed line represent median of each distribution, dotted lines are 25 th and 75 th percentiles.

velocities. Both regions notably display surges indices greater than 10, with maxima up to 18 in the Kunlun Shan and 223 in the Karakoram. Velocity data for Qilian Shan, Eastern Hindu Kush, Himalayas and Tibetan mountains were too sparse to be considered representative ( $<10$ samples in each case).

We note no clear difference in surge active phase duration between regions (Figure 11, c). The majority of surges typically last less than 3 years, with a median duration of $2.6 \pm 0.1$ years. However, the distributions are systematically heavy-tailed, with all regions displaying active phases lasting 18 years.

We finally study the distributions of duration and cumulative sum of $I P R$ (see Equation 4) for each surge over HMA. We use the latter as a crude proxy of the total energy dissipated during a given surge.

Both distributions are presented in Figure 12 and display the characteristic shape of power law (or Pareto)-like distributions. Power laws are common in geophysical systems where energy accumulated over a significant period is released rapidly (also known as avalanching systems), and arise from a wide variety of physical phenomena (criticality and self organized criticality (SOC), among others. See e.g. Turcotte (1989), Sachs et al. (2012), Åström et al. (2014), and Corral and González (2019) for 

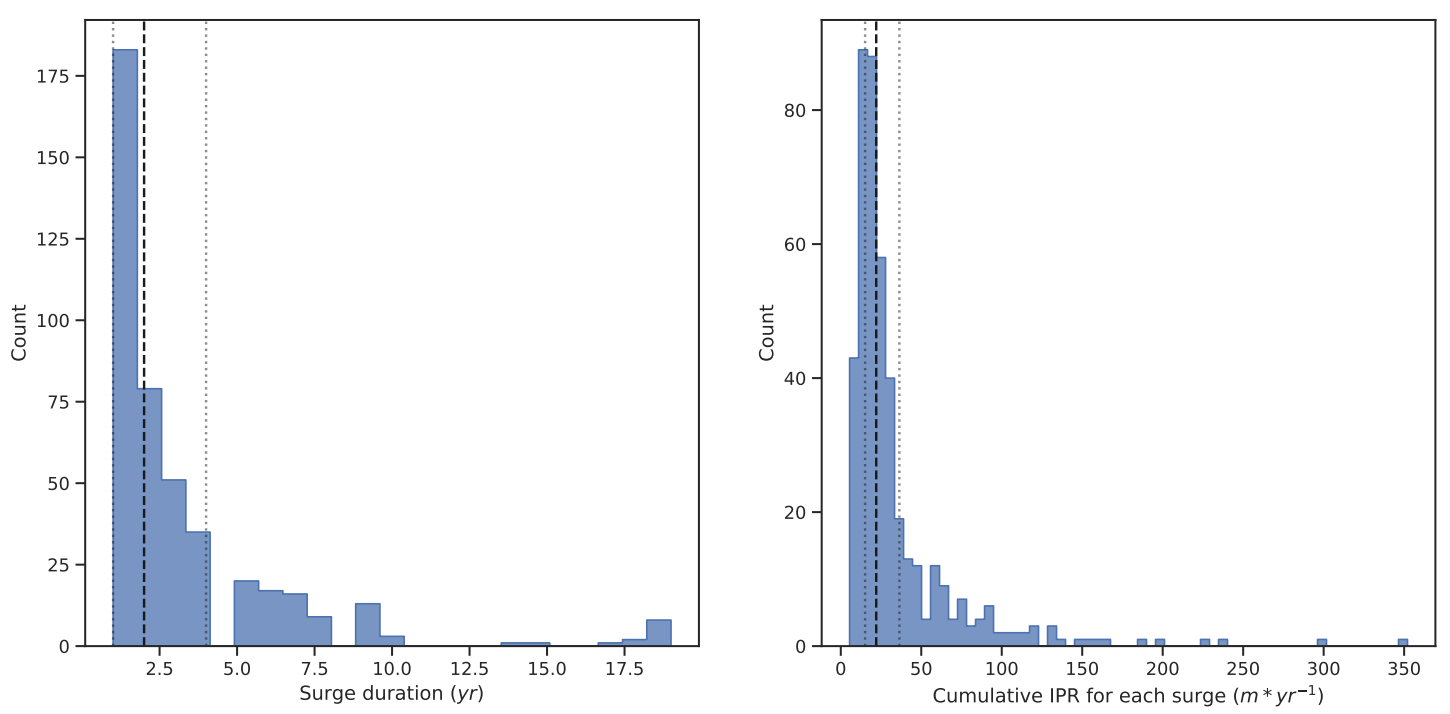

Figure 12. Distributions of surge duration and cumulative sum of IPR for the 439 surges recorded over the 245 glaciers presenting velocity data

\begin{tabular}{|c|c|c|c|}
\hline Variable & $\alpha$ & $\sigma$ & $\mathrm{R}$ \\
\hline Cumulative sum of IPR $\left(m * y r^{-1}\right)$ & 2.4 & 0.04 & 24 \\
\hline Duration of surge active phase $(y r s)$ & 1.45 & 0.03 & -6 \\
\hline
\end{tabular}

Table 3. Table of power law parameters: $\alpha$ represents the power law exponent. $\sigma$ is the standard deviation associated to $\alpha$. R represents the log-likelihood ratio between power law and exponential distributions.

more). To further study the hypothesis that the velocity anomaly during active phases and the duration of surges follow power law distributions, we use the widespread method of Clauset et al. (2009), relying on maximum likelihood estimation of power law distribution parameters (Pawitan, 2001; Bauke, 2007) and Kolmogorov-Smirnov distance minimization or log-likelihood ratio goodness-of-fit tests (See Park and Kim (1992); Press et al. (2007) for example). The proposed power law model fits the velocity anomaly during active phases active phase better than exponential models, with log-likelihood ratio (R) significantly greater than zero (see Table 3). On the other hand, the exponential model fits the duration of active phases of surges better than the best-fit power law model, with a log-likelihood ratio of -6 .

The fits between the estimated probability densities and the data are further presented in Figure 13. We find that the theoretical cumulative distribution function (CCDF) is in good agreement with the cumulative sum of IPR data. As mentioned above, the fitted distribution does not replicate active phase duration distribution as well. This is likely to be a consequence of our heavily truncated observation period: we do not highlight surges with an active phase greater than 18 years and thus truncate 


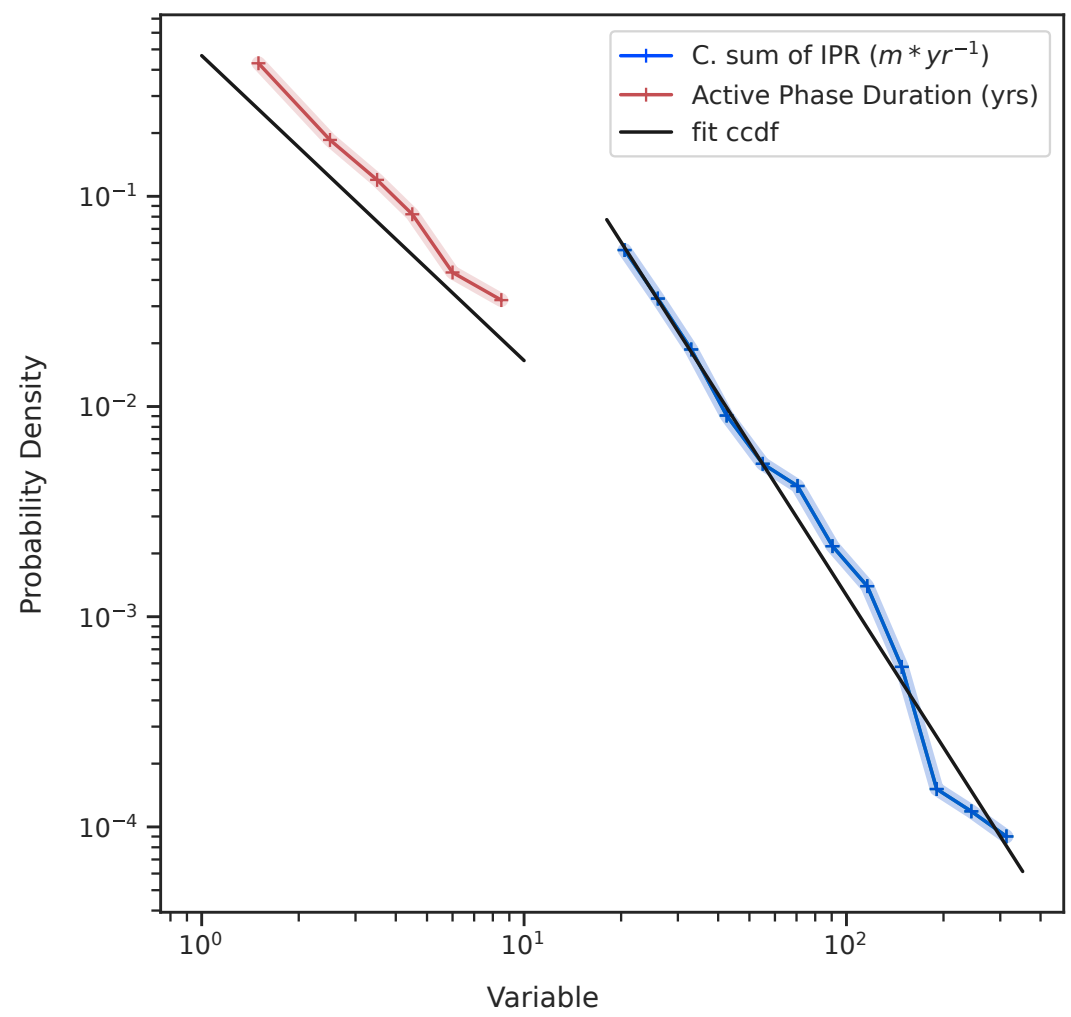

Figure 13. Estimation of empirical probability densities for the cumulative sum of IPR (blue) and surge active phase duration (red). Solid black lines indicate power law fits.

the power law's heavy tail. Similarly the yearly sample rate of the ITS_LIVE data used prevents from identifying active phases lasting less than a year, further truncating the potential power law.

\section{Discussion}

\subsection{Uncertainties}

The surge-type glacier identification criteria which we have followed are built on a number of different publicly available datasets generated in previous studies. Each of these datasets are imperfect representation of real geophysical signals and attributes, and present a level of uncertainty. For an in-depth discussion on dataset-specific uncertainties, we redirect the reader to the original publications of Brun et al. (2017), Shean et al. (2020) and Hugonnet et al. (2021) (DEMs), Gardner et al. (2019) (ITS_LIVE datasets), and Pfeffer et al. (2014) (RGI attributes). We are confident that the treatment of error and uncertainty in these previous studies has been sufficient to avoid the misinterpretation of those datasets in our study. 
https://doi.org/10.5194/tc-2021-303

Preprint. Discussion started: 6 October 2021

(c) Author(s) 2021. CC BY 4.0 License.

(c) (i)

\subsubsection{Identification of surge-type glaciers}

Our study combines different, individual criteria used in previous studies to identify glacier surging, each of which may be more or less reliable in the detection of glacier surging in different scenarios. For example, the identification of glacier surging through the monitoring of glacier terminus positions is effective when glacier terminus advance is anomalous in comparison to the local pattern of glacier retreat in response to climate conditions, or where glaciers are devoid of stagnant, debris-covered tongues which may inhibit surge propagation towards glacier termini (Quincey et al., 2015). Glacier surging and mass gain related terminus advance may be confused in some scenarios (Lv et al., 2020) and additional observations are required to more accurately interpret glacier behaviour. In this study we qualify a glacier as surging if, and only if, it presented at least two of the three discriminatory criteria outlined in sections 2.1 to 2.3. We are therefore confident that our interpretations are robust and that the prevalence of surging we document is an improvement on approaches using fewer surging criteria.

\subsubsection{Identification of individual surges, temporal variability and IPR}

In Section 3.4, we derived distributions of surge duration and intensity for every surge of each of the 245 glaciers with velocity data. While all glaciers identified have been systematically verified to be surging, individual surges of the same glacier are only derived from the velocity data. The determination of individual surges onset and termination year therefore only relies on the velocity dataset; the duration of surges is thus known up to a certain level certainty, depending on our threshold for identification ( $k$ in Equation 4). We tested the implications of different values of $k$ over the statistical attributes of the distributions of surge duration and cumulative sum of IPR and found that increasing $k$ naturally reduces the number of detected surges (Data not shown). However, the distribution of surge durations does not differ substantially for different values of $k$. On the other hand, the distribution of cumulative sum of IPR is positively biased, as a result of the truncation of lower values. Increasing the detection threshold does not affect the shape of the distributions.

\subsection{Comparison with other inventories}

Inventories of surge-type glaciers have been assembled for many sub-regions of HMA and particularly detailed studies have been carried out where hazards associated with surging have been widespread and recurring, such as the Karakoram and the Pamirs. A careful comparison of the similarities and differences between our inventory and those of previous studies is difficult because of the contrast in the methods used to identify glacier surging, the criteria used to define glacier surging and because the periods examined to identify glacier surging vary substantially between studies. General comparisons can be drawn between inventories based on remotely sensed imagery to establish the success of the methods used however (Table 4). The inventory of Goerlich et al. (2020) is based on observations of surface elevation change and glacier terminus advance in the Pamirs over the period 1968-2018 which allowed for the identification of 206 surge-type glaciers. Our observations of elevation change, surface velocity change and structural glaciology between 2000-2018 suggest 223 surge-type glaciers in the same region. The limited difference between these results may suggest that few surges in the Pamirs exhibit low magnitude elevation changes (e.g. Figure 1) and require additional observations (surface velocity) to aid surge-type glacier identification. The low rate of 
https://doi.org/10.5194/tc-2021-303

Preprint. Discussion started: 6 October 2021

(c) Author(s) 2021. CC BY 4.0 License.

(c) (i)

thinning and ice mass loss in the Pamirs (see Shean et al. (2020) for example) has also likely preserved the strong signal of elevation change associated with surging in multi-decadal geodetic studies.

In contrast, Rankl et al. (2014) identified 101 surge-type glaciers in the Karakoram from glacier surface velocity and glacier terminus observations over the period 1972-2012, which is substantially less than the 223 identified in this study using data covering the period 2000-2018. The main methodological difference between our study and Rankl et al. (2014) is our additional use of surface elevation change data and the annual resolution of the ITS_LIVE glacier surface velocity fields, which were intermittent (1992, 1993, 2003 and 2006-2013) in the study of Rankl et al. (2014). Many short duration (median 2.3 years) Karakoram glacier surges (Figure 12) may have occurred between the dates of velocity fields presented by Rankl et al. (2014) and the longer lasting mass transfer signal of the same surges has only been picked up by our subsequent analyses of glacier surface elevation change. Also focusing on the Karakoram, Bhambri et al. (2017) compiled a list of 221 surge-type glaciers, 2 fewer than our estimate, but using a wide variety of observations spanning the period 1840-2015. As a broad portion of the study period of Bhambri et al. (2017) covers the pre-satellite era, during which many short-duration or low magnitude surges could have occurred undocumented, we would suggest that our inventory of surge-type glaciers provides a more accurate estimate of the contemporary prevalence of surge-type glaciers in the Karakoram. Mukherjee et al. (2017) supplemented an inventory based on previously published results with surface elevation change datasets over the period 1964-2014 to identify 39 surge-type glaciers in the Tien Shan. Our results suggest there are 74 surge-type glaciers in the same study area. Again, the main methodological difference between our study and that of Mukherjee et al. (2017) is our use of the ITS_LIVE velocity time series, which enabled the identification of 35 additional surge-type glaciers. In contrast to the Pamirs, the substantial, longterm thinning experienced by glaciers in the Tien Shan (Bhattacharya et al., 2021) has likely dampened the signal of thickening caused by glacier surging in multi-decadal geodetic studies, thus our additional examination of surface velocity anomalies has resulted in a more complete picture of the prevalence of surge-type glaciers here. The comparisons above emphasise the benefits of a multi-factor approach to identify surge-type glaciers, particularly in regions where glacier recession and mass loss rates are high. The availability of multi-temporal, globally resolved remotely sensed datasets should facilitate the assembly of extensive, accurate surge-type glaciers inventories in the future.

\subsection{Distribution and geometry of surge and non surge-type glaciers}

We have studied the relationships between glacier geometry and surging behaviour. Our results are consistent with previous knowledge that surging-glaciers systematically present greater areas, length and elevation range than non-surge-type glaciers (Clarke et al., 1986; Hamilton and Dowdeswell, 1996; Jiskoot et al., 1998, 2000, 2003; Barrand and Murray, 2006; Grant et al., 2009; Sevestre and Benn, 2015).

Greater lengths are correlated with increased surge-affected area in glacier complexes, with up to $45 \%$ glacier area impacted in the Karakoram (Hispar Glacier). With surge-type glaciers being consistently in the higher-end of the glacier area spectrum, such considerations need to be further studied as they are likely to have a significant impact on glacier mass balance (King et al., 2021) and glacier-related hazards (Kääb et al. (2021) for example) at glacier scale. 
https://doi.org/10.5194/tc-2021-303

Preprint. Discussion started: 6 October 2021

(c) Author(s) 2021. CC BY 4.0 License.

(c) (i)

\begin{tabular}{|c|c|c|c|c|c|c|}
\hline Study & Region & Period & Number of surge-type glaciers & This study & Data sources & Evidence \\
\hline Bhambri et al. (2017) & Karakoram & 1840s-2017 & 221 & 223 & Data Landsat, ASTER, Ground Observations & $\mathrm{dT}, \mathrm{dV}, \mathrm{SF}$ \\
\hline Rankl et al. (2014) & - & 1976-2012 & 101 & - & Landsat, various Synthetic Aperture Radar (SAR) images & $\mathrm{dT}, \mathrm{dV}$ \\
\hline Sevestre and Benn (2015) & - & $1861-2013$ & 106 & - & Literature & Various \\
\hline Sevestre and Benn (2015) & Pamir & - & 820 & 223 & - & Various \\
\hline Goerlich et al. (2020) & - & 1960s-2018 & 206 & - & Landsat, Corona KH-4, Hexagon KH-9, SRTM, AW3D30 & $\mathrm{dT}, \mathrm{dH}$ \\
\hline Osipova et al. (1998); Kotlyakov et al. (2008) & - & 1973-2006 & 55 & - & Historical data, Resurs-F, ASTER & Various \\
\hline Yasuda and Furuya (2015) & Western Kunlun & 1972-1992 & 9 & 60 & Landsat, various Synthetic Aperture Radar (SAR) images & $\mathrm{dT}, \mathrm{dV}$ \\
\hline Mukherjee et al. (2017) & Tien Shan & $1964-2014$ & 39 & 74 & Landsat, Corona KH-4, Hexagon KH-9, Cartosat, SPOT & $\mathrm{dT}, \mathrm{dH}$ \\
\hline Sevestre and Benn (2015) & - & $1861-2013$ & 11 & - & Literature & Various \\
\hline
\end{tabular}

Table 4. Comparison of the number of surge-type glaciers identified by other inventory studies in sub-regions of HMA with our results. dT $=$ change in terminus position, $\mathrm{dV}=$ changes in glacier surface velocity, $\mathrm{SF}=$ surface features, $\mathrm{dH}=$ changes in glacier surface elevation

While we observe lower median surface slope for surge-type glaciers, the results are not as clear-cut as for other studies such as Sevestre and Benn (2015) for example. We however mention that we found $\approx 300$ duplicate entries in Sevestre and Benn (2015) Pamirs inventory. The inventory from Sevestre and Benn (2015) thus reflects the total number of surges reported in literature (827) rather than the number of surge-type glaciers (543) in the region. Given the overall lower surface slopes documented in the Pamirs compared to other HMA regions, the duplicated data is likely to bias the distribution towards lower values. The slight, non-statistically significant correlation between slope and surging described in our study is consistent with previous results in Yukon Territory (Clarke, 1991), Spitsbergen (Hamilton, 1992; Hamilton and Dowdeswell, 1996) and Karakoram (Bhambri et al., 2017). We however demonstrated that, in HMA, longer glaciers with gentler surface slopes are more likely to be surge-type than short steep glaciers. Length and slope thus act as independent controls on surging behaviour, a result that was first predicted in the enthalpy balance theory proposed by Benn et al. (2019).

We have shown that the aspect distributions for surge-type glaciers and non-surge-type glaciers do not substantially differ, which is consistent with previous knowledge on the studied regions (Bhambri et al., 2017; Mukherjee et al., 2017; Goerlich et al., 2020). Aspect distributions however differ in the Tibetan Mountains. We interpreted this result as the consequence of ice cap outlets outnumbering valley/mountain glaciers in this area, with the aspect of the latter being controlled by topography and geology, while the former present less topographically constrained flow. From this, we argue that, in the Tibetan Mountains, aspect has no control over surging behaviour.

\subsubsection{Impact of surges on mass balance}

In Section 3.3, we presented glacier mass changes computed by the studies of Shean et al. (2020) and Hugonnet et al. (2021) with an emphasis on the potential differences in mass balance a single, greater than decadal time period. In line with the results of Gardelle et al. (2013); Berthier and Brun (2019), we do not report any significant difference in mass budget between surgetype and non surge-type glaciers over multi-decadal timescales, for all the greater HIMAP regions. We however described marked increase in mass loss following surge cessation for two glaciers in the Karakoram. These results are consistent with the findings of Kochtitzky et al. (2019); King et al. (2021) and Bhattacharya et al. (2021). While such a mass loss is clearly 
https://doi.org/10.5194/tc-2021-303

Preprint. Discussion started: 6 October 2021

(c) Author(s) 2021. CC BY 4.0 License.

(c) (i)

identifiable in a minimal time frame after surge termination, it is likely averaged out over multi-decadal timescales. The regional distribution of mass changes over multi-decadal time scales is thus unlikely to be altered by surge-type behavior, unless a significant number of glaciers surge repeatedly during the studied period (see Bhattacharya et al. (2021) for more) or in case of extreme events. Surges will however locally lead to increased variability in a glacier's meltwater runoff and hamper the water resource availability, potentially jeopardizing human livelihoods in the glacier's vicinity. The impact of surging over more localized scales thus need to be further quantified, through the thorough study of a greater number of mass balance measurements, covering the entire surge cycle of a significant glacier sample.

\subsubsection{Temporal variability and velocities in surge active phase}

In this study, we present distributions of surge active phase duration derived from yearly ITS_LIVE velocity data. The moments of the presented distributions (here the percentiles) are in line with previous studies focusing on each individual region (Quincey et al., 2011; Yasuda and Furuya, 2015; Quincey et al., 2015; Bhambri et al., 2017; Lv et al., 2019; Goerlich et al., 2020; Paul, 2020; Zhu et al., 2021). We nonetheless demonstrated that the differences between distinct HMA regions lie in the number of surges rather than the duration of individual surges. This result contrasts with the findings of Dowdeswell et al. (1991) stating that active phases in the Pamirs typically last for 1 to 2 years, and disputes the claims of Zhu et al. (2021) than Tien Shan covers a greater range of active phase duration than other regions in HMA.

We here further dispute the claim of Goerlich et al. (2020) that active phase duration in the Pamirs is "random". The presented results indeed demonstrate that the distribution of surge active phase duration (both for HMA and the Pamirs) is more likely to be heavy-tailed or power law-like.

\subsection{On the physics of glacier surges}

Our results suggest potential power law-like and heavy-tailed distributions for a variety of surge-type glacier parameters. Using standard methods for power law validation, we most notably highlighted that the cumulative sum of IPR over the entire duration of surge active phases (as a crude proxy of energy dissipated during the active phase) potentially follows a power law distribution. The emergence of power-law distributed quantities in avalanching geophysical systems (systems that suddenly release energy slowly accumulated over a period) arises from a wide variety of physical reasons (see Corral and González (2019) for example), with the potential role of Self-Organized Criticality (Bak, 2013) in glacier surges being first discussed by Kavanaugh (2009). Given the importance of power law-generating physical phenomena in understanding geophysical dynamical systems, we emphasize the need to validate the potential power-laws described in this study with 1) complementary data (Sentinel 1 velocity data for example) providing velocity and surge active phase duration estimates over a wider range of order of magnitudes and 2) adapting the existing glacier surge models proposed by Benn et al. (2019) or Thøgersen et al. (2019) to estimate the energy dissipated during the active phase of a surge. 
https://doi.org/10.5194/tc-2021-303

Preprint. Discussion started: 6 October 2021

(c) Author(s) 2021. CC BY 4.0 License.

(c) (i)

\section{Conclusions}

In this paper, we presented a new inventory of surge-type glaciers for High Mountain Asia. This inventory is based on on a multi-factor remote sensing approach, combining yearly velocity fields (ITS_LIVE), surface elevation change datasets published in prior studies and very high-resolution satellite imagery (Bing Maps and Google Earth) to identify surge-type glaciers between 2000 and 2018. Overall, we identified 666 surge-type glaciers across HMA over the studied period, confirming 107 for which surging behaviour was believed "Probable" or "Possible", and newly identifying 491. We further studied the geometry of surge-type glaciers compared to non-surge-type glaciers and found relationships coherent with previous studies which have focused on smaller sub-samples of surge-type glaciers. We established a relationship between surging behaviour and glacier

415 size, the most important being that for glacier complexes, the area affected by surging is dependent on overall complex length following a power law relationship. The duration of the active phase of surge-type glaciers across HMA shows little variation in between greater HIMAP regions. Finally we defined the sum of velocity anomalies during a surge as a crude proxy for energy dissipated over the duration of the active phase and studied its distribution. We showed that this distribution is heavy tailed and, using standard methods for power law validation, discussed that the sum of velocity anomalies and surge duration are potentially power law distributed. We would recommend that our inventory serves as a baseline dataset in the further study of surge-type glacier characteristics.

Author contributions. GG, OK, and TB conceived the study. GG, OK and ML generated the inventory, with support from SG. The code was developed by GG (velocity workflow and data analysis). GG and OK analyzed the results with support from ML and DB. GG and OK wrote the paper and produced the figures, with contributions from all other co-authors. independent editor, and the authors have also no other competing interests to declare.

Data availability. The inventory is available at https://zenodo.org/record/5524861.

Acknowledgements. This study was supported by the Strategic Priority Research Programs of Chinese Academy of Sciences (XD A20100300, $X D A 19070202$, and $X D A 20100300)$ and the Swiss National Science Foundation (200021E_177652/1). 
https://doi.org/10.5194/tc-2021-303

Preprint. Discussion started: 6 October 2021

(c) Author(s) 2021. CC BY 4.0 License.

(c) (i)

430

\section{References}

Aðalgeirsdóttir, G., Björnsson, H., Pálsson, F., and Magnússon, E.: Analyses of a Surging Outlet Glacier of Vatnajökull Ice Cap, Iceland, Annals of Glaciology, 42, 23-28, https://doi.org/10.3189/172756405781812934, 2005.

Åström, J. A., Vallot, D., Schäfer, M., Welty, E. Z., O’Neel, S., Bartholomaus, T. C., Liu, Y., Riikilä, T. I., Zwinger, T., Timonen, J., and Moore, J. C.: Termini of Calving Glaciers as Self-Organized Critical Systems, Nature Geoscience, 7, 874-878, https://doi.org/10.1038/ngeo2290, 2014.

Bak, P.: How Nature Works: The Science of Self-Organized Criticality, Springer Science \& Business Media, 2013.

Barrand, N. E. and Murray, T.: Multivariate Controls on the Incidence of Glacier Surging in the Karakoram Himalaya, Arctic, Antarctic, and Alpine Research, 38, 489-498, https://doi.org/10.1657/1523-0430(2006)38[489:MCOTIO]2.0.CO;2, 2006.

Bauke, H.: Parameter Estimation for Power-Law Distributions by Maximum Likelihood Methods, The European Physical Journal B, 58, 167-173, https://doi.org/10.1140/epjb/e2007-00219-y, 2007.

Bazai, N. A., Cui, P., Carling, P. A., Wang, H., Hassan, J., Liu, D., Zhang, G., and Jin, W.: Increasing Glacial Lake Outburst Flood Hazard in Response to Surge Glaciers in the Karakoram, Earth-Science Reviews, 212, 103 432, https://doi.org/10.1016/j.earscirev.2020.103432, 2021.

Belo, M., Mayer, C., Smiraglia, C., and Tamburini, A.: The Recent Evolution of Liligo Glacier, Karakoram, Pakistan,and Its Present Quiescent Phase, Annals of Glaciology, 48, 171-176, https://doi.org/10.3189/172756408784700662, 2008.

Benn, D. I., Fowler, A. C., Hewitt, I., and Sevestre, H.: A General Theory of Glacier Surges, Journal of Glaciology, 65, 701-716, https://doi.org/10.1017/jog.2019.62, 2019.

Berthier, E. and Brun, F.: Karakoram Geodetic Glacier Mass Balances between 2008 and 2016: Persistence of the Anomaly and Influence of a Large Rock Avalanche on Siachen Glacier, Journal of Glaciology, 65, 494-507, https://doi.org/10.1017/jog.2019.32, 2019.

Bhambri, R., Hewitt, K., Kawishwar, P., and Pratap, B.: Surge-Type and Surge-Modified Glaciers in the Karakoram, Scientific Reports, 7 , 15 391, https://doi.org/10.1038/s41598-017-15473-8, 2017.

Bhambri, R., Hewitt, K., Kawishwar, P., Kumar, A., Verma, A., Snehmani, Tiwari, S., and Misra, A.: Ice-Dams, Outburst Floods, and Movement Heterogeneity of Glaciers, Karakoram, Global and Planetary Change, 180, 100-116, https://doi.org/10.1016/j.gloplacha.2019.05.004, 2019.

Bhambri, R., Watson, C. S., Hewitt, K., Haritashya, U. K., Kargel, J. S., Pratap Shahi, A., Chand, P., Kumar, A., Verma, A., and Govil, H.: The Hazardous 2017-2019 Surge and River Damming by Shispare Glacier, Karakoram, Scientific Reports, 10, 4685, https://doi.org/10.1038/s41598-020-61277-8, 2020.

Bhattacharya, A., Bolch, T., Mukherjee, K., King, O., Menounos, B., Kapitsa, V., Neckel, N., Yang, W., and Yao, T.: High Mountain Asian Glacier Response to Climate Revealed by Multi-Temporal Satellite Observations since the 1960s, Nature Communications, 12, 4133, https://doi.org/10.1038/s41467-021-24180-y, 2021.

Bolch, T., Pieczonka, T., Mukherjee, K., and Shea, J.: Brief Communication: Glaciers in the Hunza Catchment (Karakoram) Have Been Nearly in Balance since the 1970s, The Cryosphere, 11, 531-539, https://doi.org/10.5194/tc-11-531-2017, 2017.

Bolch, T., Shea, J. M., Liu, S., Azam, F. M., Gao, Y., Gruber, S., Immerzeel, W. W., Kulkarni, A., Li, H., Tahir, A. A., Zhang, G., and Zhang, Y.: Status and Change of the Cryosphere in the Extended Hindu Kush Himalaya Region, in: The Hindu Kush Himalaya Assessment: Mountains, Climate Change, Sustainability and People, edited by Wester, P., Mishra, A., Mukherji, A., and Shrestha, A. B., pp. 209-255, Springer International Publishing, Cham, https://doi.org/10.1007/978-3-319-92288-1_7, 2019. 
https://doi.org/10.5194/tc-2021-303

Preprint. Discussion started: 6 October 2021

(c) Author(s) 2021. CC BY 4.0 License.

\section{(c) (1)}

Brun, F., Berthier, E., Wagnon, P., Kääb, A., and Treichler, D.: A Spatially Resolved Estimate of High Mountain Asia Glacier Mass Balances from 2000 to 2016, Nature Geoscience, 10, 668-673, https://doi.org/10.1038/ngeo2999, 2017.

Christina Herzfeld, U. and Zahner, O.: A Connectionist-Geostatistical Approach to Automated Image Classification, Applied to the Analysis of Crevasse Patterns in Surging Ice, Computers \& Geosciences, 27, 499-512, https://doi.org/10.1016/S0098-3004(00)00089-3, 2001.

Chudley, T. R. and Willis, I. C.: Glacier Surges in the North-West West Kunlun Shan Inferred from 1972 to 2017 Landsat Imagery, Journal of Glaciology, 65, 1-12, https://doi.org/10.1017/jog.2018.94, 2019.

Clarke, G. K. C.: Length, Width and Slope Influences on Glacier Surging, Journal of Glaciology, 37, 236-246, https://doi.org/10.3189/S0022143000007255, 1991.

Clarke, G. K. C., Schmok, J. P., Ommanney, C. S. L., and Collins, S. G.: Characteristics of Surge-Type Glaciers, Journal of Geophysical Research: Solid Earth, 91, 7165-7180, https://doi.org/10.1029/JB091iB07p07165, 1986.

Clauset, A., Shalizi, C. R., and Newman, M. E. J.: Power-Law Distributions in Empirical Data, SIAM Review, 51, 661-703, https://doi.org/10.1137/070710111, 2009.

Consortium, R. et al.: Randolph glacier inventory-a dataset of global glacier outlines: version 6.0, Global Land Ice Measurements from Space, Colorado, USA, Tech. Rep, 2017.

Copland, L., Sharp, M. J., and Dowdeswell, J. A.: The Distribution and Flow Characteristics of Surge-Type Glaciers in the Canadian High Arctic, Annals of Glaciology, 36, 73-81, https://doi.org/10.3189/172756403781816301, 2003.

Copland, L., Sylvestre, T., Bishop, M. P., Shroder, J. F., Seong, Y. B., Owen, L. A., Bush, A., and Kamp, U.: Expanded and Recently Increased Glacier Surging in the Karakoram, Arctic, Antarctic, and Alpine Research, 43, 503-516, https://doi.org/10.1657/1938-424643.4.503, 2011.

Corral, Á. and González, Á.: Power Law Size Distributions in Geoscience Revisited, Earth and Space Science, 6, 673-697, https://doi.org/10.1029/2018EA000479, 2019.

Cuffey, K. M. and Paterson, W. S. B.: The Physics of Glaciers, Academic Press, 2010.

Dehecq, A., Gourmelen, N., Gardner, A. S., Brun, F., Goldberg, D., Nienow, P. W., Berthier, E., Vincent, C., Wagnon, P., and Trouvé, E.: Twenty-First Century Glacier Slowdown Driven by Mass Loss in High Mountain Asia, Nature Geoscience, 12, 22-27, https://doi.org/10.1038/s41561-018-0271-9, 2019.

Ding, M., Huai, B., Sun, W., Wang, Y., Zhang, D., Guo, X., and Zhang, T.: Surge-Type Glaciers in Karakoram Mountain and Possible Catastrophes alongside a Portion of the Karakoram Highway, Natural Hazards, 90, 1017-1020, https://doi.org/10.1007/s11069-017-30634, 2018.

Dowdeswell, J. A. and Williams, M.: Surge-Type Glaciers in the Russian High Arctic Identified from Digital Satellite Imagery, Journal of Glaciology, 43, 489-494, https://doi.org/10.3189/S0022143000035097, 1997.

Dowdeswell, J. A., Hamilton, G. S., and Hagen, J. O.: The Duration of the Active Phase on Surge-Type Glaciers: Contrasts between Svalbard and Other Regions, Journal of Glaciology, 37, 388-400, https://doi.org/10.3189/S0022143000005827, 1991.

Gao, Y., Liu, S., Qi, M., Xie, F., Wu, K., and Zhu, Y.: Glacier-Related Hazards Along the International Karakoram Highway: Status and Future Perspectives, Frontiers in Earth Science, 0, https://doi.org/10.3389/feart.2021.611501, 2021.

Gardelle, J., Berthier, E., Arnaud, Y., and Kääb, A.: Region-Wide Glacier Mass Balances over the Pamir-Karakoram-Himalaya during 1999\&ndash;2011, The Cryosphere, 7, 1263-1286, https://doi.org/10.5194/tc-7-1263-2013, 2013. 
https://doi.org/10.5194/tc-2021-303

Preprint. Discussion started: 6 October 2021

(c) Author(s) 2021. CC BY 4.0 License.

(c) (i)

Gardner, A. S., Moholdt, G., Scambos, T., Fahnstock, M., Ligtenberg, S., van den Broeke, M., and Nilsson, J.: Increased West Antarctic and Unchanged East Antarctic Ice Discharge over the Last 7 Years, The Cryosphere, 12, 521-547, https://doi.org/10.5194/tc-12-521-2018, 2018.

Gardner, A. S., Fahnestock, M., and Scambos, T. A.: ITS_LIVE Regional Glacier and Ice Sheet Surface Velocities, Data archived at National Snow and Ice Data Center, 2019.

Gardner, J. S. and Hewitt, K.: A Surge of Bualtar Glacier, Karakoram Range, Pakistan: A Possible Landslide Trigger, Journal of Glaciology, 36, 159-162, https://doi.org/10.3189/S0022143000009394, 1990.

510 Goerlich, F., Bolch, T., and Paul, F.: More Dynamic than Expected: An Updated Survey of Surging Glaciers in the Pamir, Earth System Science Data, 12, 3161-3176, https://doi.org/10.5194/essd-12-3161-2020, 2020.

Grant, K. L., Stokes, C. R., and Evans, I. S.: Identification and Characteristics of Surge-Type Glaciers on Novaya Zemlya, Russian Arctic, Journal of Glaciology, 55, 960-972, https://doi.org/10.3189/002214309790794940, 2009.

Hamilton, G. S.: Investigation of Surge-Type Glaciers in Svalbard, Thesis, University of Cambridge, https://doi.org/10.17863/CAM.27506, 1992.

Hamilton, G. S. and Dowdeswell, J. A.: Controls on Glacier Surging in Svalbard, Journal of Glaciology, 42, 157-168, https://doi.org/10.3189/S0022143000030616, 1996.

Häusler, H., Ng, F., Kopecny, A., and Leber, D.: Remote-Sensing-Based Analysis of the 1996 Surge of Northern Inylchek Glacier, Central Tien Shan, Kyrgyzstan, Geomorphology, 273, 292-307, https://doi.org/10.1016/j.geomorph.2016.08.021, 2016.

Herzfeld, U. C., Clarke, G. K. C., Mayer, H., and Greve, R.: Derivation of Deformation Characteristics in Fast-Moving Glaciers, Computers \& Geosciences, 30, 291-302, https://doi.org/10.1016/j.cageo.2003.10.012, 2004.

Hewitt, K.: Glacier Surges in the Karakoram Himalaya (Central Asia), Canadian Journal of Earth Sciences, 6, 1009-1018, https://doi.org/10.1139/e69-106, 1969.

Hewitt, K.: Tributary Glacier Surges: An Exceptional Concentration at Panmah Glacier, Karakoram Himalaya, Journal of Glaciology, 53, 181-188, https://doi.org/10.3189/172756507782202829, 2007.

Hewitt, K. and Liu, J.: Ice-Dammed Lakes and Outburst Floods, Karakoram Himalaya: Historical Perspectives on Emerging Threats, Physical Geography, 31, 528-551, https://doi.org/10.2747/0272-3646.31.6.528, 2010.

Hugonnet, R., McNabb, R., Berthier, E., Menounos, B., Nuth, C., Girod, L., Farinotti, D., Huss, M., Dussaillant, I., Brun, F., and Kääb, A.: Accelerated Global Glacier Mass Loss in the Early Twenty-First Century, Nature, 592, 726-731, https://doi.org/10.1038/s41586-02103436-z, 2021.

Imran, M. and Ahmad, U.: Geospatially Analysing the Dynamics of the Khurdopin Glacier Surge Using Multispectral and Temporal Remote Sensing and Ground Observations, Natural Hazards, 108, 847-866, https://doi.org/10.1007/s11069-021-04708-7, 2021.

Jennings, S. J. A. and Hambrey, M. J.: Structures and Deformation in Glaciers and Ice Sheets, Reviews of Geophysics, 59, e2021RG000 743, https://doi.org/10.1029/2021RG000743, 2021.

535 Jiskoot, H.: Glacier Surging, in: Encyclopedia of Snow, Ice and Glaciers, pp. 415-428, Springer Dordrecht, 2011.

Jiskoot, H., Boyle, P., and Murray, T.: The Incidence of Glacier Surging in Svalbard: Evidence from Multivariate Statistics, Computers \& Geosciences, 24, 387-399, https://doi.org/10.1016/S0098-3004(98)00033-8, 1998.

Jiskoot, H., Murray, T., and Boyle, P.: Controls on the Distribution of Surge-Type Glaciers in Svalbard, Journal of Glaciology, 46, 412-422, https://doi.org/10.3189/172756500781833115, 2000. 
https://doi.org/10.5194/tc-2021-303

Preprint. Discussion started: 6 October 2021

(c) Author(s) 2021. CC BY 4.0 License.

(c) (i)

Jiskoot, H., Pedersen, A. K., and Murray, T.: Multi-Model Photogrammetric Analysis of the 1990s Surge of Sortebræ, East Greenland, Journal of Glaciology, 47, 677-687, https://doi.org/10.3189/172756501781831846, 2001.

Jiskoot, H., Murray, T., and Luckman, A.: Surge Potential and Drainage-Basin Characteristics in East Greenland, Annals of Glaciology, 36, 142-148, https://doi.org/10.3189/172756403781816220, 2003.

Kääb, A., Jacquemart, M., Gilbert, A., Leinss, S., Girod, L., Huggel, C., Falaschi, D., Ugalde, F., Petrakov, D., Chernomorets, S., Dokukin, M., Paul, F., Gascoin, S., Berthier, E., and Kargel, J. S.: Sudden Large-Volume Detachments of Low-Angle Mountain Glaciers - More Frequent than Thought?, The Cryosphere, 15, 1751-1785, https://doi.org/10.5194/tc-15-1751-2021, 2021.

Kavanaugh, J. L.: Exploring Glacier Dynamics with Subglacial Water Pressure Pulses: Evidence for Self-Organized Criticality?, Journal of Geophysical Research: Earth Surface, 114, https://doi.org/10.1029/2008JF001036, 2009.

King, O., Bhattacharya, A., and Bolch, T.: The Presence and Influence of Glacier Surging around the Geladandong Ice Caps, North East Tibetan Plateau, Advances in Climate Change Research, 12, 299-312, https://doi.org/10.1016/j.accre.2021.05.001, 2021.

Kochtitzky, W., Jiskoot, H., Copland, L., Enderlin, E., Mcnabb, R., Kreutz, K., and Main, B.: Terminus Advance, Kinematics and Mass Redistribution during Eight Surges of Donjek Glacier, St. Elias Range, Canada, 1935 to 2016, Journal of Glaciology, 65, 565-579, https://doi.org/10.1017/jog.2019.34, 2019.

Kotlyakov, V. M., Osipova, G. B., and Tsvetkov, D. G.: Fluctuations of Unstable Mountain Glaciers: Scale and Character, Annals of Glaciology, 24, 338-343, https://doi.org/10.3189/S0260305500012416, 1997.

Kotlyakov, V. M., Osipova, G. B., and Tsvetkov, D. G.: Monitoring Surging Glaciers of the Pamirs, Central Asia, from Space, Annals of Glaciology, 48, 125-134, https://doi.org/10.3189/172756408784700608, 2008.

Kraaijenbrink, P. D. A., Bierkens, M. F. P., Lutz, A. F., and Immerzeel, W. W.: Impact of a Global Temperature Rise of 1.5 Degrees Celsius on Asia's Glaciers, Nature, 549, 257-260, https://doi.org/10.1038/nature23878, 2017.

560 Lalande, M., Ménégoz, M., Krinner, G., Naegeli, K., and Wunderle, S.: Climate Change in the High Mountain Asia in CMIP6, Earth System Dynamics Discussions, pp. 1-56, https://doi.org/10.5194/esd-2021-43, 2021.

Li, Y.-J., Ding, Y.-J., Shangguan, D.-H., and Wang, R.-J.: Regional Differences in Global Glacier Retreat from 1980 to 2015 , Advances in Climate Change Research, 10, 203-213, https://doi.org/10.1016/j.accre.2020.03.003, 2019.

Lovell, A. M., Carr, J. R., and Stokes, C. R.: Topographic Controls on the Surging Behaviour of Sabche Glacier, Nepal (1967 to 2017 ), Remote Sensing of Environment, 210, 434-443, https://doi.org/10.1016/j.rse.2018.03.036, 2018.

Lv, M., Guo, H., Lu, X., Liu, G., Yan, S., Ruan, Z., Ding, Y., and Quincey, D. J.: Characterizing the Behaviour of Surge- and Non-Surge-Type Glaciers in the Kingata Mountains, Eastern Pamir, from 1999 to 2016, The Cryosphere, 13, 219-236, https://doi.org/10.5194/tc-13-219$2019,2019$.

Lv, M., Guo, H., Yan, J., Wu, K., Liu, G., Lu, X., Ruan, Z., and Yan, S.: Distinguishing Glaciers between Surging and Advancing by Remote Sensing: A Case Study in the Eastern Karakoram, Remote Sensing, 12, 2297, https://doi.org/10.3390/rs12142297, 2020.

Mansell, D., Luckman, A., and Murray, T.: Dynamics of Tidewater Surge-Type Glaciers in Northwest Svalbard, Journal of Glaciology, 58, 110-118, https://doi.org/10.3189/2012JoG11J058, 2012.

Meier, M. F. and Post, A.: What Are Glacier Surges?, Canadian Journal of Earth Sciences, 6, 807-817, https://doi.org/10.1139/e69-081, 1969.

575 Mouginot, J. and Rignot, E.: Ice Motion of the Patagonian Icefields of South America: 1984-2014, Geophysical Research Letters, 42, 1441-1449, https://doi.org/10.1002/2014GL062661, 2015. 
https://doi.org/10.5194/tc-2021-303

Preprint. Discussion started: 6 October 2021

(c) Author(s) 2021. CC BY 4.0 License.

(c) (i)

Muhammad, S. and Tian, L.: Mass Balance and a Glacier Surge of Guliya Ice Cap in the Western Kunlun Shan between 2005 and 2015 , Remote Sensing of Environment, 244, 111 832, https://doi.org/10.1016/j.rse.2020.111832, 2020.

Mukherjee, K., Bolch, T., Goerlich, F., Kutuzov, S., Osmonov, A., Pieczonka, T., and Shesterova, I.: Surge-Type Glaciers in the Tien Shan

(Central Asia), Arctic, Antarctic, and Alpine Research, 49, 147-171, https://doi.org/10.1657/AAAR0016-021, 2017.

Murray, T., Strozzi, T., Luckman, A., Jiskoot, H., and Christakos, P.: Is There a Single Surge Mechanism? Contrasts in Dynamics between Glacier Surges in Svalbard and Other Regions, Journal of Geophysical Research: Solid Earth, 108, https://doi.org/10.1029/2002JB001906, 2003.

Osipova, G., Tchetinnikov, A., and Rudak, M.: Catalogue of Surging Glaciers of Pamir, Mater. Glyatsiol. Issled., 85, 3-136, 1998.

Osmonov, A., Bolch, T., Xi, C., Kurban, A., and Guo, W.: Glacier Characteristics and Changes in the Sary-Jaz River Basin (Central Tien Shan, Kyrgyzstan) - 1990-2010, Remote Sensing Letters, 4, 725-734, https://doi.org/10.1080/2150704X.2013.789146, 2013.

Park, W. and Kim, Y.: Goodness-of-Fit Tests for the Power-Law Process, IEEE Transactions on Reliability, 41, 107-111, https://doi.org/10.1109/24.126680, 1992.

Paul, F.: A 60-Year Chronology of Glacier Surges in the Central Karakoram from the Analysis of Satellite Image Time-Series, Geomorphology, 352, 106 993, https://doi.org/10.1016/j.geomorph.2019.106993, 2020.

Paul, F., Strozzi, T., Schellenberger, T., and Kääb, A.: The 2015 Surge of Hispar Glacier in the Karakoram, Remote Sensing, 9, 888, https://doi.org/10.3390/rs9090888, 2017.

Pawitan, Y.: In All Likelihood: Statistical Modelling and Inference Using Likelihood, OUP Oxford, 2001.

Pfeffer, W. T., Arendt, A. A., Bliss, A., Bolch, T., Cogley, J. G., Gardner, A. S., Hagen, J.-O., Hock, R., Kaser, G., Kienholz, C., Miles, E. S., Moholdt, G., Mölg, N., Paul, F., Radić, V., Rastner, P., Raup, B. H., Rich, J., Sharp, M. J., and Consortium, T. R.: The Randolph Glacier Inventory: A Globally Complete Inventory of Glaciers, Journal of Glaciology, 60, 537-552, https://doi.org/10.3189/2014JoG13J176, 2014.

Press, W. H., Teukolsky, S. A., Vetterling, W. T., and Flannery, B. P.: Numerical Recipes 3rd Edition: The Art of Scientific Computing, Cambridge University Press, 2007.

Pritchard, H., Murray, T., Luckman, A., Strozzi, T., and Barr, S.: Glacier Surge Dynamics of Sortebræ, East Greenland, from Synthetic Aperture Radar Feature Tracking, Journal of Geophysical Research: Earth Surface, 110, https://doi.org/10.1029/2004JF000233, 2005.

Quincey, D. J., Braun, M., Glasser, N. F., Bishop, M. P., Hewitt, K., and Luckman, A.: Karakoram Glacier Surge Dynamics, Geophysical Research Letters, 38, https://doi.org/10.1029/2011GL049004, 2011.

Quincey, D. J., Glasser, N. F., Cook, S. J., and Luckman, A.: Heterogeneity in Karakoram Glacier Surges, Journal of Geophysical Research: Earth Surface, 120, 1288-1300, https://doi.org/10.1002/2015JF003515, 2015.

605 Rankl, M., Kienholz, C., and Braun, M.: Glacier Changes in the Karakoram Region Mapped by Multimission Satellite Imagery, The Cryosphere, 8, 977-989, https://doi.org/10.5194/tc-8-977-2014, 2014.

Raymond, C. F.: How Do Glaciers Surge? A Review, Journal of Geophysical Research: Solid Earth, 92, 9121-9134, https://doi.org/10.1029/JB092iB09p09121, 1987.

Round, V., Leinss, S., Huss, M., Haemmig, C., and Hajnsek, I.: Surge Dynamics and Lake Outbursts of Kyagar Glacier, Karakoram, The Cryosphere, 11, 723-739, https://doi.org/10.5194/tc-11-723-2017, 2017.

Sachs, M. K., Yoder, M. R., Turcotte, D. L., Rundle, J. B., and Malamud, B. D.: Black Swans, Power Laws, and Dragon-Kings: Earthquakes, Volcanic Eruptions, Landslides, Wildfires, Floods, and SOC Models, The European Physical Journal Special Topics, 205, 167182, https://doi.org/10.1140/epjst/e2012-01569-3, 2012. 
https://doi.org/10.5194/tc-2021-303

Preprint. Discussion started: 6 October 2021

(c) Author(s) 2021. CC BY 4.0 License.

\section{(c) (1)}

Sevestre, H. and Benn, D. I.: Climatic and Geometric Controls on the Global Distribution of Surge-Type Glaciers: Implications for a Unifying

Model of Surging, Journal of Glaciology, 61, 646-662, https://doi.org/10.3189/2015JoG14J136, 2015.

Shangguan, D., Liu, S., Ding, Y., Guo, W., Xu, B., Xu, J., and Jiang, Z.: Characterizing the May 2015 Karayaylak Glacier Surge in the

Eastern Pamir Plateau Using Remote Sensing, Journal of Glaciology, 62, 944-953, https://doi.org/10.1017/jog.2016.81, 2016.

Sharp, M.: Surging Glaciers: Behaviour and Mechanisms, Progress in Physical Geography: Earth and Environment, 12, 349-370, https://doi.org/10.1177/030913338801200302, 1988.

Shean, D. E., Bhushan, S., Montesano, P., Rounce, D. R., Arendt, A., and Osmanoglu, B.: A Systematic, Regional Assessment of High Mountain Asia Glacier Mass Balance, Frontiers in Earth Science, 0, https://doi.org/10.3389/feart.2019.00363, 2020.

Steiner, J. F., Kraaijenbrink, P. D. A., Jiduc, S. G., and Immerzeel, W. W.: Brief Communication: The Khurdopin Glacier Surge Revisited Extreme Flow Velocities and Formation of a Dammed Lake in 2017, The Cryosphere, 12, 95-101, https://doi.org/10.5194/tc-12-95-2018, 2018.

Sund, M., Eiken, T., Hagen, J. O., and Kääb, A.: Svalbard Surge Dynamics Derived from Geometric Changes, Annals of Glaciology, 50, 50-60, https://doi.org/10.3189/172756409789624265, 2009.

Thøgersen, K., Gilbert, A., Schuler, T. V., and Malthe-Sørenssen, A.: Rate-and-State Friction Explains Glacier Surge Propagation, Nature Communications, 10, 2823, https://doi.org/10.1038/s41467-019-10506-4, 2019.

Truffer, M., Kääb, A., Harrison, W. D., Osipova, G. B., Nosenko, G. A., Espizua, L., Gilbert, A., Fischer, L., Huggel, C., Craw Burns, P. A., and Lai, A. W.: Chapter 13 - Glacier Surges, in: Snow and Ice-Related Hazards, Risks, and Disasters (Second Edition), edited by Haeberli, W. and Whiteman, C., pp. 417-466, Elsevier, https://doi.org/10.1016/B978-0-12-817129-5.00003-2, 2021.

Turcotte, D. L.: Fractals in Geology and Geophysics, in: Fractals in Geophysics, edited by Scholz, C. H. and Mandelbrot, B. B., Pure and Applied Geophysics, pp. 171-196, Birkhäuser, Basel, https://doi.org/10.1007/978-3-0348-6389-6_10, 1989.

Wendt, A., Mayer, C., Lambrecht, A., and Floricioiu, D.: A Glacier Surge of Bivachny Glacier, Pamir Mountains, Observed by a Time Series of High-Resolution Digital Elevation Models and Glacier Velocities, Remote Sensing, 9, 388, https://doi.org/10.3390/rs9040388, 2017.

$\mathrm{Xu}$, J., Shangguan, D., and Wang, J.: Recent Surging Event of a Glacier on Geladandong Peak on the Central Tibetan Plateau, Journal of Glaciology, pp. 1-7, https://doi.org/10.1017/jog.2021.86, 2021.

Yasuda, T. and Furuya, M.: Glacier Surge in West Kunlun Shan, NW Tibet Detected by Synthetic Aperture Radar, in: Conference Proceedings of 2013 Asia-Pacific Conference on Synthetic Aperture Radar (APSAR), pp. 61-62, 2013.

640 Yasuda, T. and Furuya, M.: Dynamics of Surge-Type Glaciers in West Kunlun Shan, Northwestern Tibet, Journal of Geophysical Research: Earth Surface, 120, 2393-2405, https://doi.org/10.1002/2015JF003511, 2015.

Zhou, S., Yao, X., Zhang, D., Zhang, Y., Liu, S., and Min, Y.: Remote Sensing Monitoring of Advancing and Surging Glaciers in the Tien Shan, 1990-2019, Remote Sensing, 13, 1973, https://doi.org/10.3390/rs13101973, 2021.

Zhu, Q., Ke, C.-Q., and Li, H.: Monitoring Glacier Surges in the Kongur Tagh Area of the Tibetan Plateau Using Sentinel-1 SAR Data,

Geomorphology, 390, 107 869, https://doi.org/10.1016/j.geomorph.2021.107869, 2021. 